\title{
A preliminary chronological study to understand the construction phases of a Late Copper-Early Bronze Age kurgan (kunhalom)
}

\author{
Gábor Szilágyi $^{1,2}$, Katalin Náfrádi ${ }^{1}$, Pál Sümegi ${ }^{1,3}$ \\ ${ }^{1}$ Department of Geology and Palaeontology, University of Szeged, Szeged, Hungary \\ ${ }^{2}$ Department of Nature Protection, Hortobágyi National Park Directorate, Debrecen, Hungary \\ ${ }^{3}$ Research Centre for the Humanities, Institute of Archaeology, Hungarian Academy of Sciences, Budapest, \\ Hungary
}

Received: January 29, 2018; accepted: July 31, 2018

The aim of this study is to identify the milestones of landscape evolution around the Ecse Mound (Karcag-Kunmadaras, Hortobágy National Park, Hungary) in the Holocene period by sedimentological and malacological analysis of strata underneath and within the body of the kurgan concerned, including that of the same characteristics of the artificially piled layers. An undisturbed core drilling was carried out and the sedimentological properties of both the mound and of the substrate baserock were revealed, analysis of which has been supported by three radiocarbon (AMS) measurements. The baserock formation during the last phase of the Ice Age, Middle and Upper Pleniglacial, and Late Glacial phases was followed by soil development in the Holocene, while the mound was constructed in two phases at the end of the Copper Age by the communities of the Pit Grave (Yamna or Ochre Grave) Culture. By publishing these preliminary data, it is also intended to draw attention to the need of focused research efforts by standardized methodology in kurgan research, in order to make the results of different studies consistent and comparable.

Keywords: kurgan, sedimentology, malacology, chronology, Early Bronze Age

*Corresponding author: Gábor Szilágyi; Department of Nature Protection, Hortobágyi National Park Directorate, Sumen utca 2., H-4024 Debrecen, Hungary

E-mail: szilagyigabor@hnp.hu

This is an open-access article distributed under the terms of the Creative Commons Attribution-NonCommercial 4.0 International License, which permits unrestricted use, distribution, and reproduction in any medium for noncommercial purposes, provided the original author and source are credited, a link to the CC License is provided, and changes - if any - are indicated. 


\section{Introduction}

The Eurasian steppe and forest steppe zones are estimated to have once extended from Mongolia to the Danube delta (Bohn et al. 2007) over an 8-13 billion $\mathrm{km}^{2}$ area before human agricultural and industrial activities have begun (Wesche and Treiber 2012). Various studies, primarily botanical in scope, have proved that the Pannonic forest steppe of the Great Hungarian Plain in the Carpathian Basin is part of this zone (Borhidi 1956, 2003; Zólyomi 1957, 1987; Zólyomi and Fekete 1994; Molnár et al. 2012) that was cut off by the uplift of the Carpathian Mountains, as a result of which it has developed as a detached habitat island (Molnár and Kun 2000). This once vast natural ecosystem has mostly been ruined or transformed (Szirmai et al. 2005) by the network of settlements, roads, and railroads, increasing agricultural activity, particularly the highly motorized and chemically enhanced intensive crop farming and animal husbandry. The most dramatic changes have taken place in the Ukraine, where only $5 \%-10 \%$ of the indigenous steppe and forest steppe vegetation has subsisted within this vegetation zone (Sudnik-Wójcikowska and Moysiyenko 2013). A very similar human encroachment and its effects have taken their toll in Kazakhstan, where $90 \%$ of the former steppe has been turned into arable land, since the announcement of the Virgin Lands Campaign movement in the 1950s (Rachkovskaya and Bragina 2012).

The same anthropogenic processes have influenced the transformation of the Pannonic forest steppes developed in the Great Hungarian Plains for the past 100-150 years (Molnár et al. 2014; Deák et al. 2015). Therefore, Hungarian nature conservancy and particularly the national park directorates situated in the Great Plains play a significant role, also from an international perspective (Dengler et al. 2014), in the conservation of primary forest steppe and steppe areas, as well as in the extension and reconnection of habitat fragments based on the existing network of protected areas (Balázs 2006). This nature conservation task is particularly difficult in the case of loess steppes, since they predominate in chernozem soils, while these highly fertile areas have long been cultivated as croplands (Kelemen et al. 2010; Török et al. 2011). This is the main reason for the existence of the few remaining examples of Pannonic forest steppe and loess steppe habitats in the Great Plains, mostly sustained in ditch slopes, balks, as well as on burial and watch mounds (Zólyomi 1969; Tóth 1998; Csathó 2009; Penksza et al. 2011; Balázs and Kustár 2012; Bede et al. 2014, 2015; Csathó et al. 2015; Deák et al. 2015).

These mounds have a one ha surface area on average (Deák et al. 2015, 2016), and despite their small size plays a pivotal role in the conservation of the steppe and forest steppe biota, because their botanical and zoological assets can be particularly diverse. This property can be attributed to the very structure of these mounds, i.e., their pyramidal shape with rather steep slopes. These steep, conic slopes were difficult or impossible to plough, and depending on their exposure, very diverse microhabitats and diverse microclimatic conditions have developed on them (Vona and Penksza 2004; Sudnik-Wójcikowska et al. 2011).

Burial mounds are the most important objects of nature conservation efforts aiming at the restoration of the original vegetation and soil conditions, since they were built on 
the natural ground surface, and the earth around the burial site was used as building material (Barczi et al. 2003, 2004, 2006; Joó et al. 2007). Thus, contemporary soil types can be studied in the building strata of the mounds (Bede et al. 2014). Beyond the pedological research, by the careful study of plant remains, primarily pollen and phytoliths (Sümegi 2001, 2002; Persaits et al. 2008, 2014; Persaits and Sümegi 2011, 2015), it is possible to reconstruct the vegetation of the area within the period of the construction. This research can yield very precise data on the soil conditions and vegetation before and during the construction of the mounds in the heart of the Carpathian Basin. As the soil beneath these earth-pyramids has not developed any longer (Khomutova et al. 2007; Kashirskaya et al. 2010; Demkin et al. 2014; Lomov et al. 2017), the study of the natural original soil can reveal the soil conditions before the mounds were constructed.

The geo-archeological study of these burial and dwelling mounds is very important, since these were the very first archeological sites to be included in geo-archeological research studies (Jefferson 1783; Vanuxem 1843; Forchhammer et al. 1851). Mounds are among the earliest objects of interest of archeology in Hungary, and Flóris Rómer (one of the founding fathers of Hungarian archeology) was the first to study them scientifically in the vicinity of Vaskút (Rómer 1868a, 1868b, 1868c). The first full-scale scientific register of these man-made landforms was also compiled by Flóris Rómer (1878), but he carried out in-depth studies of kurgans in Bihar and on a set of kurgans in Trans-Danubia (in the region of Szalacska, Tihany, and Tátika) dating back to the Bronze and Early Iron Age (Pásztor 2004). These archeological undertakings then lead to further scientific studies in Hungary (Párducz 1959; Kulcsár 1989; Köhegyi and Vörös 1999, 2000, 2002; Vörös 2002).

The date of origin of the mounds has been a most important question since the early period of archeological excavations. Not only did the mounds vary, but also the time of their construction ranged within a wide period of time. The Hungarian term "kunhalom" (meaning "Cumanian mound") (Horvát 1825; Jerney 1851; Gyárfás 1870; Gárdonyi 1893, 1914; Györffy 1921) is highly problematic, since this is the umbrella term for all types of mounds without consideration of their function or date of origin (Tóth and Tóth 2003; Tóth 2006; Barczi et al. 2009; Petö and Barczi 2011; Dani and Horváth 2012). This term persisted despite archeologists' warnings of the problems and misunderstandings it has caused, both in chronology and functional classification, since this term denotes Late Neolithic and Middle Bronze Age tells, Late Copper and Early Bronze Age kurgans, as well as Iron Age burial mounds, and burial mounds of Scythian, Sarmatian, Hungarian, and Cumanian origin. As Makkay (1964) has pointed out, regardless of their function whether tells, burial mounds, watch and border mounds, cultic mounds, they are all labeled as "kunhalom."

There have been assumptions (Bede et al. 2014, 2015), before this study, that the Ecse mound had been built by communities of the Pit Grave (Yamna) Culture (Merpert 1974; Gimbutas 1980; Rassamakin 1994), considering the similarities in shape, orientation, and stratigraphy of this earth-pyramid, and the comparative geomorphological research of other mounds in the Hortobágy region (Sümegi 1992; Barczi et al. 2003, 2004, 2006; Joó et al. 2007; Sümegi and Szilágyi 2011; 
Szilágyi et al. 2013). Findings and data from this artificially piled layer correlate with the radiocarbon data from 80 to 100 samples from the East European Plains, as the infiltration of the Pit Grave (Yamna) Culture to the Carpathian Basin from there took place in several waves; they define the third wave, or the beginning of the so-called classic phase, i.e., Horizon A (Morgunova and Khokhlova 2006, 2013).

Without accelerator mass spectrometry (AMS) or radiocarbon data, it is impossible to identify the culture of origin, since mounds were built in the Great Hungarian Plain throughout millennia, including in the area studied, by various cultures and peoples, like Scythians, Sarmatians, early Hungarians, and later Cumans (Tóth and Tóth 2003, Tóth 2006). Mounds were built in the Hortobágy and its broader region as early as $3300 \mathrm{BC}$ (first appearance of the peoples of the Pit Grave Culture) until as late as the 15 th century, which is a 4,900- to 5,000-year timespan.

Archeological research papers rarely report on the fact of which nature conservationists are well aware of, i.e., that early archeological excavations and research methodologies took a toll on the mounds, leading to either their full or partial disintegration in most cases. Several of the archeological sites were left without reconstruction (their central part dug up, transacted and the soil deposited beside the mound). What all these excavations share in common is that the soil was not filled back. The reconstruction of these mounds would require a systematic program requiring substantial financial resources (Bede and Czukor 2015). This also encouraged the authors to follow a different methodology of large diameter core drilling as a sample and information source in the chronology and environmental history studies.

This issue can only be tackled if the initial phase of each study includes stratigraphical and chronological analyses, so that the very function and age of the mound are revealed (Sümegi et al. 2015a). Following up on Borsy's observations (1968), the first such examinations were carried out on the section of the "Örhalom" at Sárrétudvari (Sümegi 1992), and on the "Szálkahalom," Hortobágy, by drilling and sampling (Sümegi 1988). These pilot studies have led to the elaboration of a methodology of mound research (Sümegi 2001, 2002, 2003).

Microstratigraphic sampling, sedimentological, geo-chemical, petrographic, and malacological analyses were the primary source of information guiding the methodology development. Samples were taken from the archeological excavation transects (by the archeologist Ibolya Nepper Módy) of the "Örhalom," Sárrétudvari, as the excavation trenches and illegal earth extraction made mapping and core drilling precise and easy. In addition, samples for radiocarbon analyses were collected from this same site to determine the age of specific strata (Sümegi 1992, 2004a).

The development of the methodology continued, and further Neolithic and Bronze Age tells (Sümegi 2009, 2013; Sümegi et al. 1998, 2002, 2013a), and kurgans of the Hortobágy were involved (Sümegi and Szilágyi 2011; Szilágyi et al. 2013). The kurgans of the Hortobágy included the "Ecse-halom" (Sümegi 2012), which would be discussed in the following sections of this paper. 


\section{Methodology}

It might be justified to ask why the methodology of undisturbed core drilling was chosen instead of archeological excavation, particularly in the case of this kurgan damaged in the 20th century (Bede et al. 2014, 2015, 2016). Firstly, there are financial reasons, since the cost of drilling and the analysis of the drilling sample were only a fraction of that of an archeological excavation. Since several human activities, among them archeological excavations, have had serious negative nature conservation consequences for the kurgans throughout the Great Hungarian Plain, all of them are ex lege protected by the Hungarian national legislation. In addition, on the top of all that, Ecse Mound is located within the first national park of Hungary. The first major kurgan research took place in the southern part of the Great Hungarian Plain, at Kétegyháza, between 1966 and 1968, when Gyula Gazdapusztai excavated 17 graves from 11 kurgans (Ecsedy 1979). Findings from the Bodrogkeresztúr and Boleraz cultures were unearthed from the Holocene paleosoil beneath the kurgans and the soil layers of the kurgans (Ecsedy 1973); the body of the kurgans contained graves from later ages (by Scythians and Sarmatians). Some of the graves were then plundered during the Great Migration Period (Ecsedy 1979).

Similar to the geo-archeological analysis at archeological sites (Fig. 1), the first phase of studying mounds is to carry out geomorphologic research (Figs 2 and 3) on the site (geo-archeological protocol; Sümegi 1994-1999, 2002, 2003; Bede et al. 2014). As a second phase, by geologic drilling, the different layers and their development boundaries can be mapped, followed by undisturbed core sampling (Fig. 4), or in the case of destroyed or disintegrated mounds, by establishing the geologic section by drilling the slopes. This geologic profile or drilling section aims to first identify the sediment types based on the international unconsolidated standards (Troels-Smith 1955) and on the sediment color chart (Munsell 2000). In this way, based on the results of the mapping, coring, and excavation samplings, the sequence of strata can be mapped and delineated.

This protocol is pivotal in any mound research, since the development of a mound might have had different stages, also representing different functions; e.g., a burial mound could have been used as a lookout post, or a structure (church or other cultic/ religious building, etc.) may have been built on top. Thus, delineating the particular layers, and the macroscopic and stratigraphic analyses thereof, are of particular importance. Measuring magnetic susceptibility (MS) has proved to be one of the best methods to yield stratigraphic data (Sümegi 2012; Bede et al. 2014, 2015; Sümegi et al. 2015a).

Environmental magnetic analyses were carried out on bulk samples (An et al. 1991; Rousseau and Kukla 1994; Sun and Liu 2000; Zhu et al. 2004). Samples were taken at 2-4 cm intervals. Prior to the start of the measurement, all samples were crushed in a glass mortar after weighing. Then, the samples were encased in plastic boxes and dried in air in an oven at $40{ }^{\circ} \mathrm{C}$ for $24 \mathrm{~h}$. Afterward, magnetic susceptibilities were measured at a frequency of $2 \mathrm{kHz}$ using an MS2 Bartington MS meter with a MS2E high resolution sensor (Dearing 1994). All of the samples were measured thrice and the average values of MS were computed and reported. 


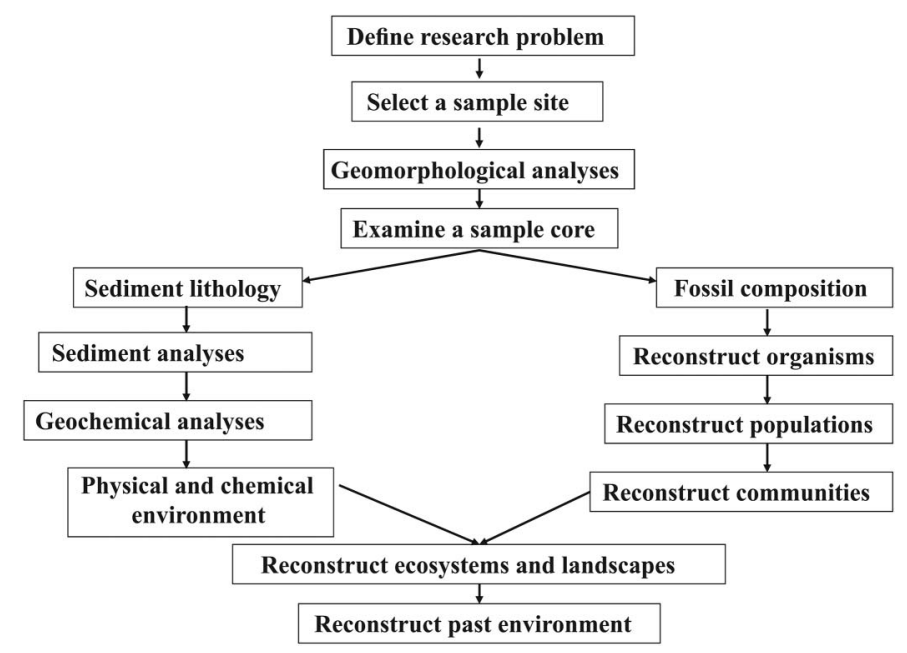

Fig. 1

Stages in a Quaternary paleoecological study (redrawn after Birks and Birks 1980)

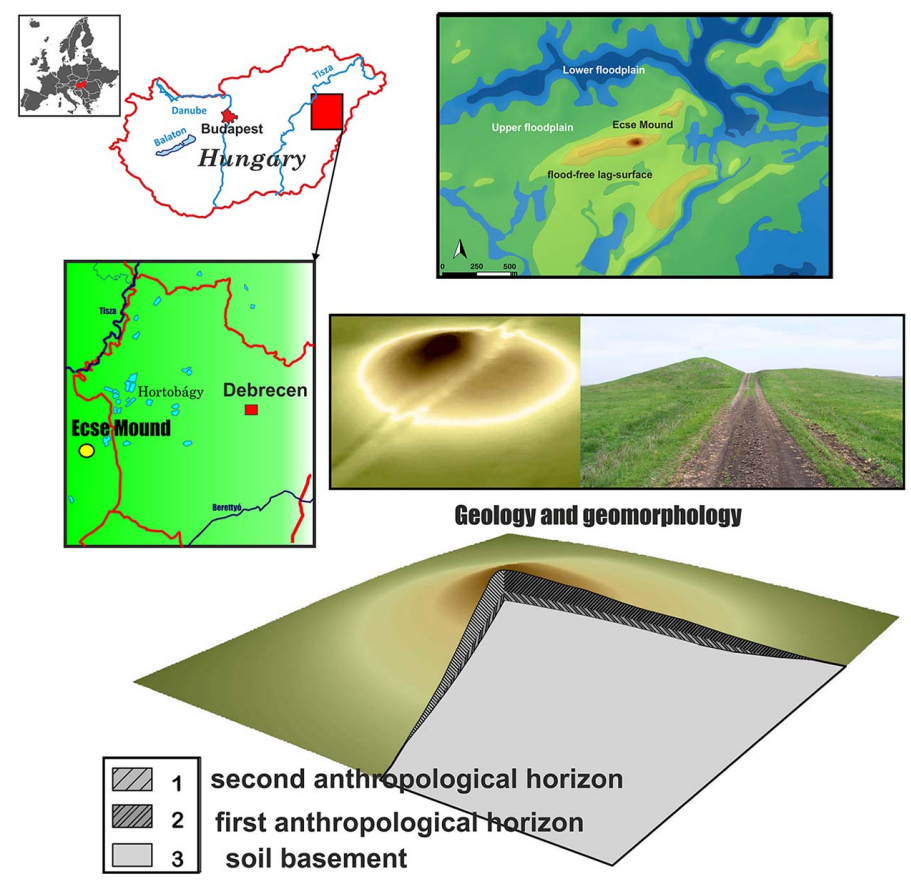

Fig. 2

Location, geomorphology, and observed stratigraphy of the Ecse Mound in the Hortobágy, NE Hungary 


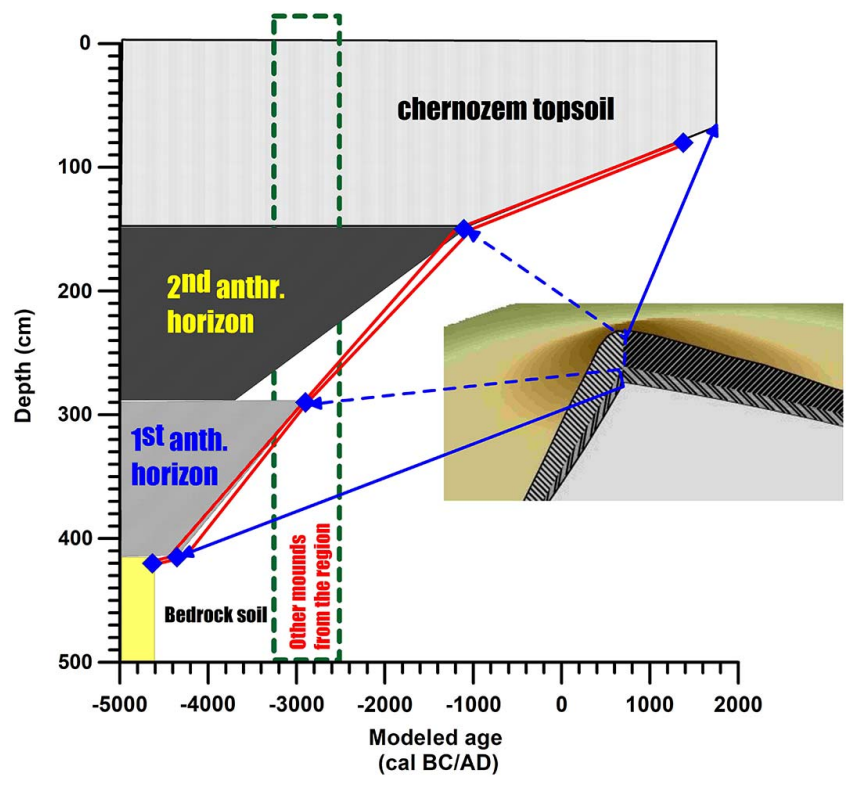

Fig. 3

3D detailed section of the reconstructed Ecse Mound. 1: the second construction layer of the mound; 2: the first construction layer of the mound; 3: the surface of the paleosoil under the mound (Bede et al. 2015)

In addition to MS, macroscopic and mechanical strata analyses, as well as variance in organic content, carbonate and mineral particle composition and their changes are also considered in the identification of strata. These soil properties, just like MS, have to be measured at 2-4 cm intervals (Sümegi et al. 2015a). Denser, i.e., $1 \mathrm{~cm}$ or less intervals have not proved to yield more precise information because of the postgenetic changes, most importantly those caused by bioturbation.

The grain size composition of sedimentological samples was carried out using the laser-sedigraph method. First, the samples were pretreated with $1 \mathrm{M} \mathrm{HCl}$ and $\mathrm{H}_{2} \mathrm{O}_{2}$ to remove carbonate and organic content, respectively (for a more detailed description of the pretreatment process, see Konert and Vandenberghe, 1997). All of the samples were measured for 42 intervals between 0.0001 and $0.5 \mathrm{~mm}$ using an Easy Laser Particle Sizer 2.0 and Fritsch sieves in Szeged (Hungary). For loss of ignition (LOI) examination, subsamples were taken at every $2-4 \mathrm{~cm}$ interval and the LOI method was applied, commonly used for the analysis of the organic and carbonate content on calcareous sediments (Dean 1974).

A new, so-called sequential extraction method (Dániel 2004) with a longestablished history in the analysis of the geochemical composition of lacustrine sediments was adopted in this study. From the complete procedure, the step of water extraction for unseparated samples was sufficient to suit our analytical needs, as was 


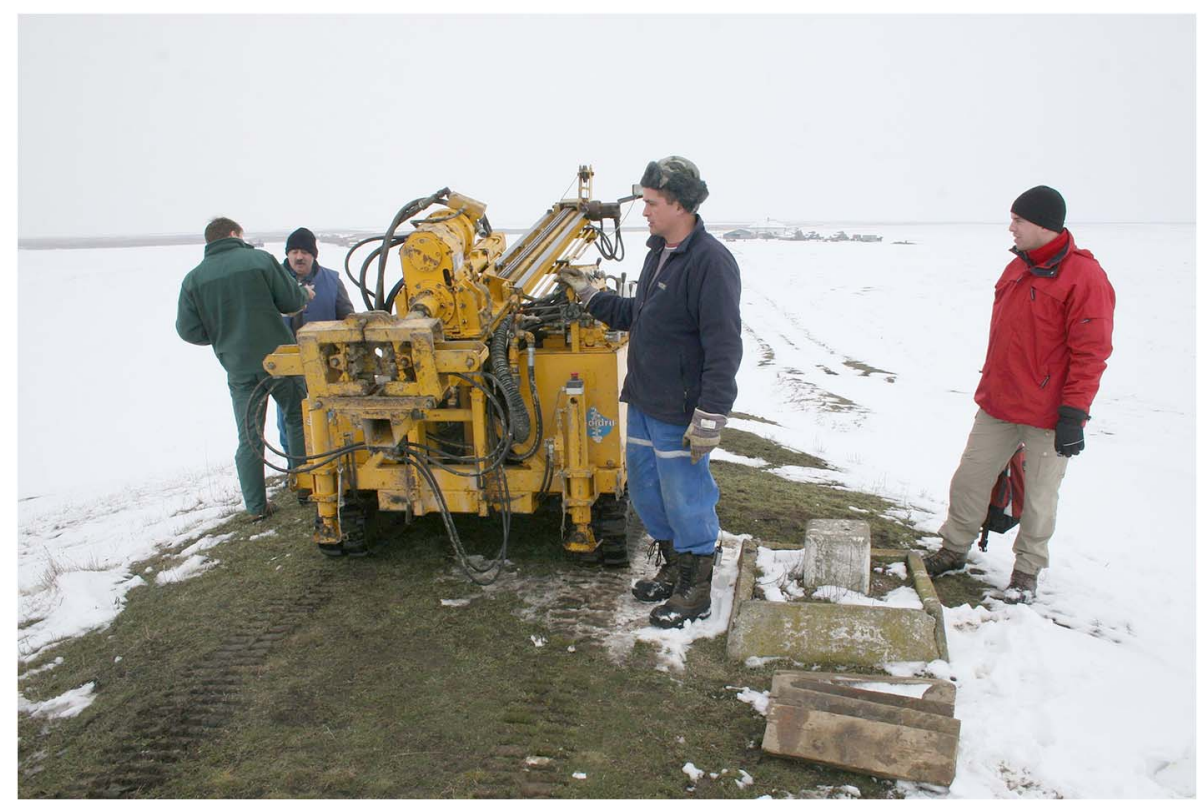

Fig. 4

Undisturbed core process on the surface of the Ecse Mound at Karcag in the pollen-free winter time of 2012

shown by previous work (Dániel 2004; Sümegi et al. 2013b); the most important paleohydrological and paleoecological data originate from water extraction samples.

Therefore, the geochemical results from water extraction samples will be shown as follows: the results from the geochemical analyses are plotted against depth. Distilled water was purified using a Millipore fife 5 Plus Water Purification System for water extraction samples. An amount of $100 \mathrm{ml}$ distilled and purified water was added to $1.0 \mathrm{~g}$ sample and was shaken for $1 \mathrm{~h}$, and then the water extract elements of $\mathrm{Na}, \mathrm{K}, \mathrm{Ca}$, $\mathrm{Mg}$, and Fe were analyzed using a Perkin-Elmer AAS spectrometer (Dániel 2004).

The macroscopic, physical, and chemical analyses made the mapping of the sequence of the sediment layers and layer boundaries possible. More precise chronology can only be achieved by radiocarbon and AMS analyses (Gazdapusztai 1968; Ecsedy 1979; Molnár et al. 2004, 2013; Molnár and Svingor 2011; Barczi et al. 2012; Dani and Horváth 2012). Additional information can be obtained with the optically stimulated luminescence (OSL) analyses (Liritzis et al. 2013) of wattle-and-daub fragments or pottery remains conserved in the layers. On the other hand, it is important to note that pottery and wattle-and-daub fragments had been piled up with the soil, and can originate from the very same culture that created the mound itself, but also from earlier cultures. The OSL analysis of the pottery and wattle-and-daub fragments may result in the false conclusion that some layers are older than their actual age (Gazdapusztai 1968). 
The radiocarbon analysis of the shells of terrestrial or fresh water snails and bivalves mixed in with the earth of the mounds also yield sufficient dating information (Gulyás et al. 2010); therefore, this method was selected in the case of the Ecse-halom (Ecse Mound), Karcag.

AMS dating measurements were carried out in the internationally referenced AMS laboratory of Seattle, WA, USA. Three snail shells from the core sequence of the Ecse Mound at Karcag were prepared for radiocarbon dating and the radiocarbon data have been shown in this preliminary paper. Certain herbivorous gastropods are known to yield reliable ages for dating deposits of the past $40 \mathrm{kys}$ with no or minimal error on the scale of perhaps a couple of hundreds of years. It is still acceptable on the scale of a multiple mollusk shell-based study (Sümegi and Hertelendi 1998; Pigati et al. 2004, 2010, 2013; Újvári et al. 2014). The preparation of the samples and the actual steps of the measurement followed the methods of Hertelendi et al. $(1989,1992)$ and Molnár et al. (2013). Shells were ultrasonically washed and dried at room temperature. Surficial contaminations and carbonate coatings were removed by pretreatment with weak acid etching $(2 \% \mathrm{HCl})$ before graphitization. Conventional radiocarbon ages were converted to calendar ages using the Calib 7.0 software (Table 1) and the most recent Intcal13 calibration curve (Reimer et al. 2014).

Further analyses are in progress beyond the three radiocarbon (AMS) measurements described in this paper, i.e., a further six samples and measurements are under preparation, and samples are being cleaned. In addition, the full drilling sample of the Ecse Mound is being analyzed for pollen, phytolith, and malacological records. Once the research is complete, an overarching article is to be published, also including previous results of the petrographical, botanical, and geomorphological studies (Bede et al. 2014, 2015, 2016). The current article is to share the important geo-archeological findings made recently with peer researchers of geo-archeology, since it is strongly believed that the current results can contribute to the methodology of dating the mounds. These results can also add to previous research articles providing them with another dimension.

Table 1

Uncal BP data and calibrated chronological data from the core sequence of the Ecse Mound at Karcag

\begin{tabular}{lccccccc}
\hline $\begin{array}{l}\text { Depth } \\
(\mathrm{cm})\end{array}$ & Material & $\begin{array}{c}\text { uncal BP } \\
\text { (year) }\end{array}$ & \pm & $\begin{array}{c}\text { cal BP } \\
\text { (year) }\end{array}$ & \pm & $\begin{array}{c}\text { cal BC } \\
\text { (year) }\end{array}$ & Code \\
\hline $289-290$ & $\begin{array}{c}\text { Unio crassus } \\
\text { shell fragments }\end{array}$ & 4,281 & 27 & 4,849 & 21 & $2,921-2,879$ & $\begin{array}{l}\text { D-AMS } \\
\text { 006516 }\end{array}$ \\
\hline $415-416$ & $\begin{array}{c}\text { Chondrula } \\
\text { tridens shell }\end{array}$ & 5,475 & 30 & 6,261 & 52 & $4,364-4,260$ & $\begin{array}{c}\text { D-AMS } \\
006517\end{array}$ \\
\hline $580-581$ & Anisus spirorbis \\
shell & 10,266 & 37 & 12,091 & 165 & $10,207-9,877$ & $\begin{array}{c}\text { D-AMS } \\
006514\end{array}$ \\
\hline
\end{tabular}




\section{Study Area}

The Ecse Mound (in Hungarian Ecse-halom) is located in the Great Hungarian Plain, in Jász-Nagykun-Szolnok County, in the area of the historical Nagykunság (Greater Cumania), in the Hortobágy region, within the Hortobágy National Park, $12 \mathrm{~km}$ north-northeast of the town of Karcag (Fig. 2). It is a border point between the administrative areas of the settlements of Karcag and Kunmadaras, found in the heart of the special forest steppe region, based on the modified Holdridge bioclimatic system (Szelepcsényi et al. 2014a, 2018) and map (Fig. 5). The central coordinates of the Ecse Mound are N47²5’31.11”, E20 57'47.71’; absolute height: $93.5 \mathrm{~m}$ asl; relative height: $5.5 \mathrm{~m}$; length: $75.5 \mathrm{~m}$, width: $67.5 \mathrm{~m}$ (Fig. 2).

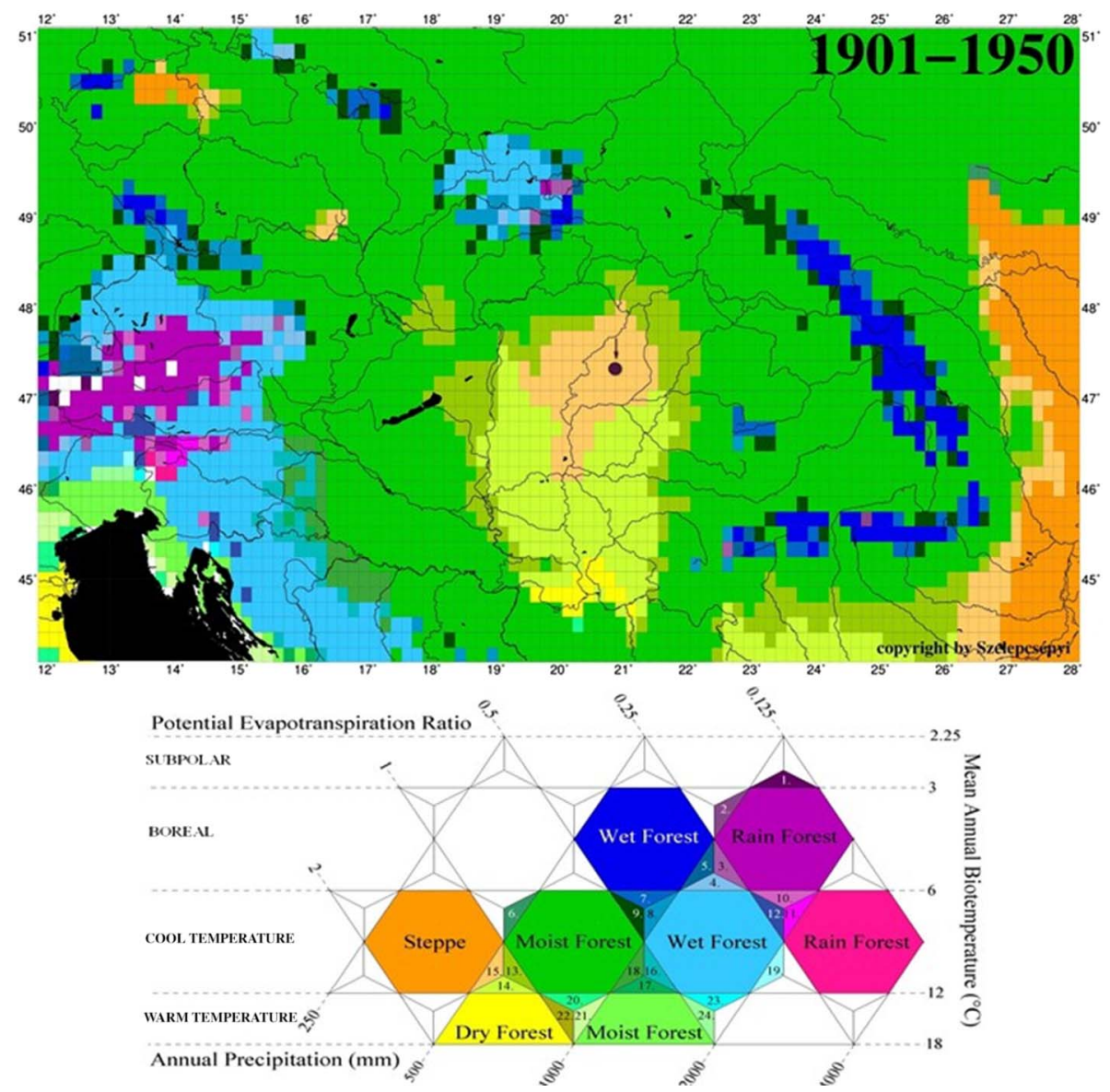

Fig. 5

Position of Ecse Mound on a spatial distribution of the Carpathian Region's core and transitional life zones for the beginning of 20th century, based on the Holdridge-modified life zone system (Szelepcsényi et al. 2014a, 2014b, 2018) 
The Ecse Mound (Fig. 2) itself is located on an elevated point in the landscape, on a remnant surface covered by Pleistocene infusion loess; it shows connections with the loess landscape of the Nagykunság area, and it is basically its northeastern protrusion that wedges into the Holocene alluvium of the Hortobágy. The mound rises on the eastern end of a slightly elevated, elongated loess ridge that is clearly separable from its surroundings on the basis of its vegetation and geomorphology. The traces of a ditch that was created when the earth was piled up on the mound are barely perceivable around the mound (Sümegi 2012); this filled up, geomorphologically hardly detectable ditch is more visible along the northwestern and northern edges.

The roughly circular mound, slightly elongated along its west-east axis, has been considerably deformed in the course of the past centuries (Fig. 2). The most apparent change is the deep cut through the center of the mound in an east-west direction, which has served as a road of local significance since medieval times (Fig. 2); due to continuous abrasion and erosion cuts (Fig. 3), it now has cut many meters deep into the body of the mound (Bukovszki and Tóth 2008; Kovács 2013). A border line of medieval origin (Fig. 2), which is still visible just to the north of the road in the form of a border ditch, was established along it (Fig. 2). This dirt road (practically a road cut deep in the soil) running across the Ecse Mound was shaped by hundreds of years of use and consequent erosion. It was already used in the Middle Ages, since a road of local interest ran this way, connecting the village of Kunkápolnás and the town of Nádudvar (Elek 2008). Later on (after the destructions of the Late Ottoman Period), it lost its significance, although the locals still use it to this day. The continuation of the road to the east is the Ecse barrage, which enables the crossing of the deeper parts of the Kunkápolnás marsh system (Bede et al. 2014, 2015, 2016).

The Ecse mound is first mentioned (Gyárfás 1883; Benedek and Zádor-Zsoldos 1998 ) in a charter describing village borders (Fig. 6) from 1521 (in the form "Echehalma"). In the Early Modern Era, it was the border point between the destroyed medieval villages of Asszonyszállás and Kápolnás. Today, it lies on the administrative border between Karcag and Kunmadaras; the borderline breaks in an angle on the top of the mound.

Manuscript maps from the 18th to 19th centuries and later printed maps consistently represent the entire area of the mound as pasture (Bede et al. 2016). In the beginning of the 20th century, however, its southern half was ploughed due to the increased demand for arable land, and already in 1943, this agricultural usage is presented. In the wider vicinity of the mound, farmsteads, dirt roads, ditches, embankments, grasslands, and lower lying swamps can be found.

The occurrence of about 90 species has been detected on the kurgan to date. Characteristic species are Aegilops cylindrica, Agropyron cristatum, Androsace elongata, Bassia sedoides, Carthamus lanatus, Linaria biebersteinii, Muscari comosum, Ranunculus pedatus, Salvia nemorosa, and Verbascum phoeniceum (Bede et al. 2016). Although the Ecse mound is not among the most valuable mounds in terms of plant species composition, regionally it certainly represents significant natural value, especially thanks to the presence of species characteristic of loess grasslands (Bede et al. 2014, 2015, 2016). The kurgan rises above its marshy, alkaline 


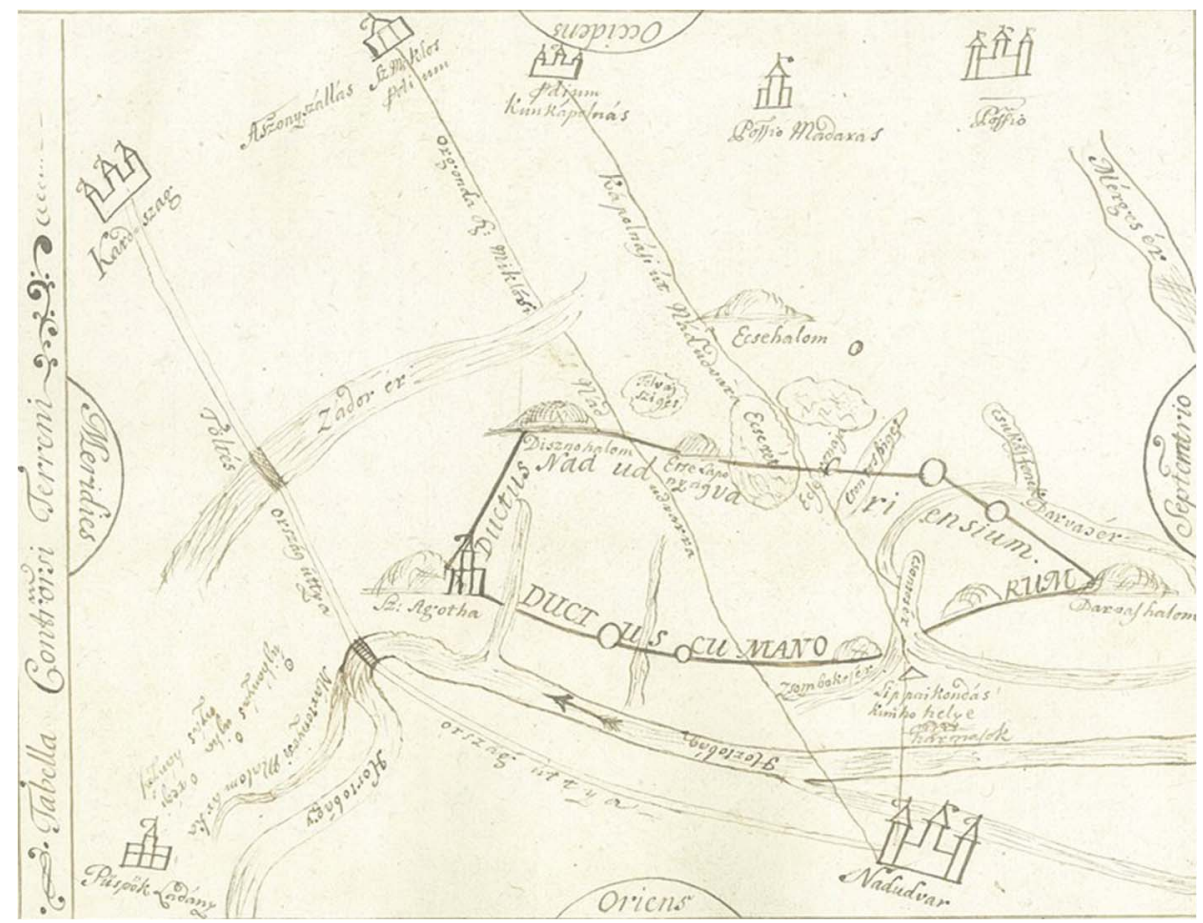

Fig. 6

Draft map of the 1521 land survey, prepared in 1759 (Kováts 1784-1787)

environment; thus, most of its surface is covered by a loess grassland association (Salvio nemorosae-Festucetum rupicolae) and its derivatives (Fig. 7). The mounds are characteristic refuges for the survival of such habitat types, having a significant conservation value, even the plant association itself (Joó 2003; Illyés and Bölöni 2007; Horváth et al. 2011). In the northern half of the Ecse Mound, loess grassland in fairly good condition can be found. Crested wheatgrass, characteristic for the dry vegetation of loess bluffs, forms only a few smaller patches beside the top and on the northern side. In the southern half of the mound, vegetation is secondary, uncharacteristic dry grass, a fallow zone unploughed for decades (Bede et al. 2016). But even this area already contains a few loess grassland species. The steep, south-looking side immediately to the south of the top is covered by a community of dry ruderal species, and this is separated by a fairly sharp border from the other vegetation zones. On the road cutting through the mound in an east-west direction, the tracks are flanked by trampled weed associations. Arboreal vegetation is only sparsely present in the area. In summary, it can be stated that the vegetation of the Ecse Mound is in a fairly good condition, partly due to its maintenance by regular, but not excessive, grazing, and mowing. 


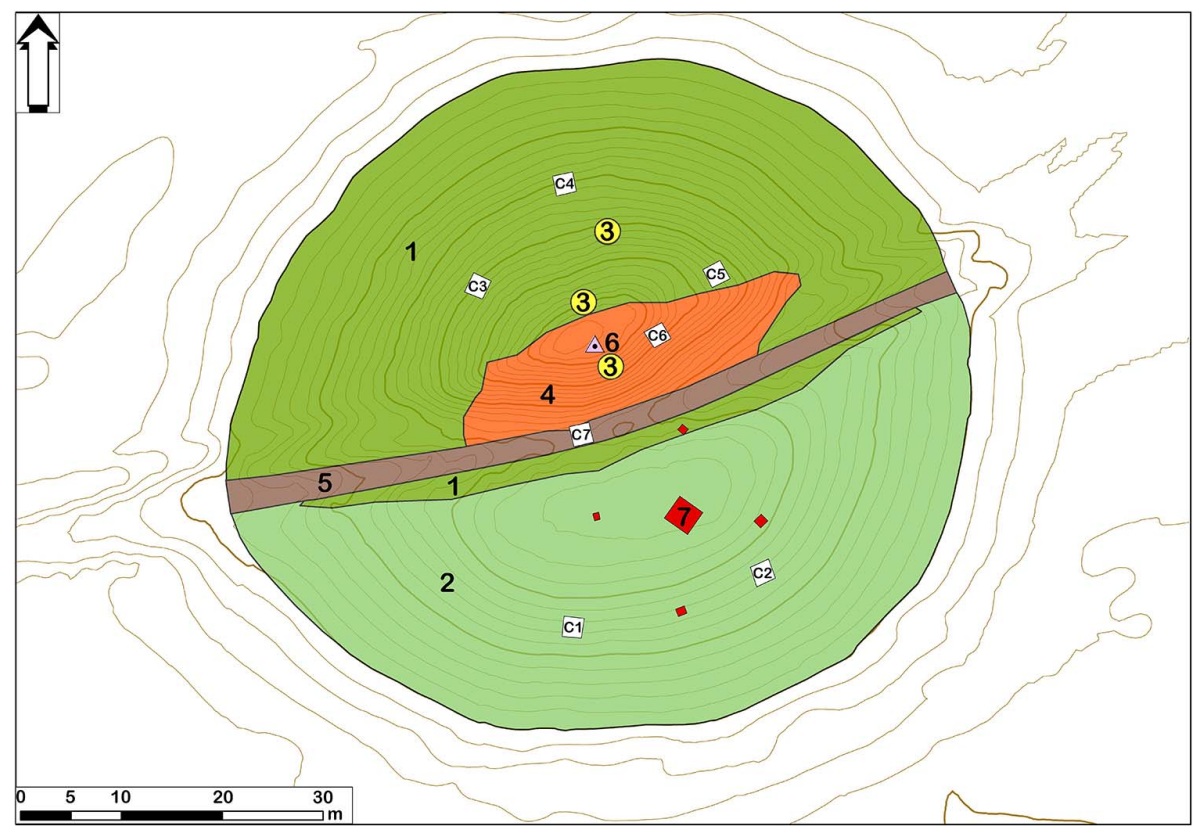

Fig. 7

Vegetation map of Ecse Mound (Bede et al. 2014, 2016). 1: loess grassland; 2: characterless dry grassland with loessy elements; 3: crested wheatgrass stands; 4: extremely dry, ruderal plant association of weeds; 5: used dirt road with weed colonies; 6: triangulation point; 7: surface concrete parts of the military observation tower base; C1, C2, C3, C4, C5, C6, and C7: coenological sampling plots

The coring was conducted at the highest elevation, next to the geodetic triangulation point land surveying triangle, in the crested wheatgrass population, in January 2012, on a cold winter day, under frozen soil and pollen-free conditions, in order to reduce disturbance caused by the drilling.

\section{Results}

The AMS-based chronology assessment of the Ecse Mound investigated the bedrock and the first few artificially piled layers (Table 1). The radiocarbon analysis has shown that the accumulation of the bedrock was still an ongoing process at the end of the Ice Age, as the baserock of soil development, the top layer of the series of fluvial strata (Fig. 8) developed (Table 1) at the end of the Ice Age within the PleistoceneHolocene transitional layer (Ralska-Jasiewiczowa et al. 2003; Rasmussen et al. 2006; Walker et al. 2009).

Based on the radiocarbon-dated soil development chronology data of the Carpathian Basin (Willis et al. 1997; Sümegi 2004b; Sümegi and Molnár 2007; 


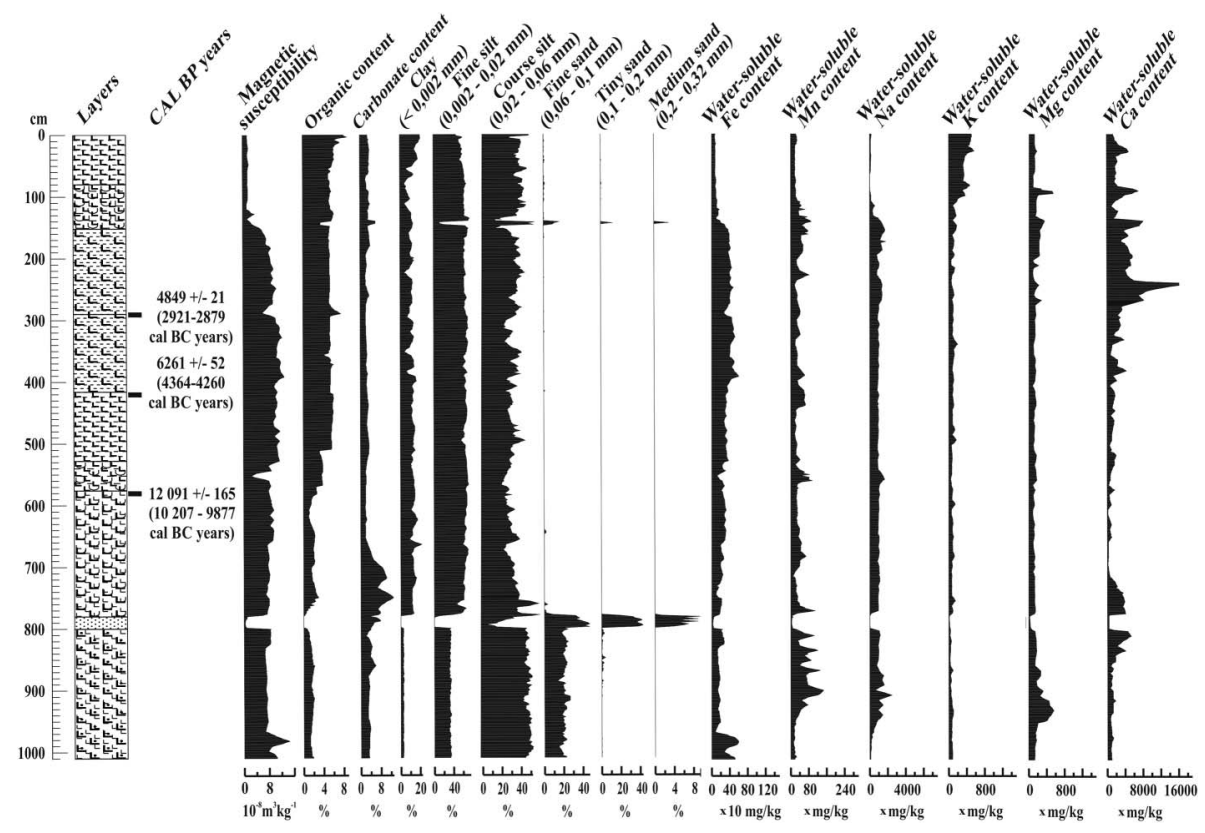

Fig. 8

Radiocarbon-dated sedimentological, magnetic susceptibility data, water-soluble Fe, $\mathrm{Mn}, \mathrm{Na}, \mathrm{K}, \mathrm{Mg}, \mathrm{Ca}$, organic and carbonate content from the undisturbed core sequence of Ecse Mound in the Hortobágy

Sümegi et al. 2012; Sümegi and Náfrádi 2015), soil development is assumed to have started at the beginning of the Holocene on the silt and carbon-rich fluvial sediment (Fig. 8) that had accumulated up until the end of the Ice Age. Holocene climatic and vegetation conditions, and consequent soil development, are estimated to have started within the period of cc. $11,500-10,500 \mathrm{cal} \mathrm{BP}=9,500-8,500 \mathrm{cal} \mathrm{BC}$ in the plain region (Willis et al. 1997, 1998). This period falls in line with the Mesolithic Age, as the radiocarbon measurements of soil layers in the Rejtek and Petényi caves, with findings from the Mesolithic Age, have proved (Sümegi et al. 2012; Sümegi and Náfrádi 2015). The environment of the Ecse Mound during the Ice Age was a floodplain that partially dried out at the end of the Mesolithic Age, resulting in a hydromorphic soil development on the slightly elevated so-called Ecse Plateau, where the Ecse Mound is situated (Fig. 2). As a result, a polyhedral soil structure with substantial organic material content had developed, which is very similar to the development of chernozem soils (Stefanovits 1963, 1972; Szabolcs 1966; Michéli et al. 2005; Minasny et al. 2009; Fuchs 2012). Since soil development took place right on the baserock, and no rearrangement of layers in a sediment pool occurred, or no natural (or even artificial) cover layer developed, the beginning and end of soil development cannot be dated precisely (Willis et al. 1997, 1998; Sümegi 1998, 2001, 2002, 2003, 2004b; Sümegi et al. 2012; Sümegi and Náfrádi 2015). 
The AMS data (Table 1) retrieved from C. tridens terrestrial snail shell remain unearthed from the intact soil layer undoubtedly indicate that soil development was still in an active phase $6,261 \pm 52$ cal BP $(4,364-4,260$ BC), i.e., at the beginning of the Copper Age (Raczky 1988, 1995; Vaday 2004; Szilágyi 2008). The transition of the late Neolithic and Copper Ages was a time-transgressive process (Gyucha et al. 2004, 2006; Parkinson 2006), which means that there is no definite division line in chronology, but rather a time interval of changes. Taking this into consideration, the substrate soil beneath the Ecse Mound could very likely have already developed in the Copper Age, as the calibrated BC dating indicates.

The shell fragments of the aquatic bivalve $U$. crassus found in the first artificially piled layer of terrestrial sediment suggest external, most probably human influence. The AMS analysis data of these fragments (Table 1) $4,849 \pm 21$ cal BP (2,921-2,879 BC) unambiguously indicate that the first layer of the mound was piled up at the end of the Copper Age (Vaday 2004). Thus, it can be stated that the mound was constructed by a local community of the Pit Grave (Yamna) Culture (Gazdapusztai 1968; Ecsedy 1979; Horváth et al. 2013), and that its people predominated within the research area at the late Copper Age-Bronze Age period.

Based on the radiocarbon measurements in the geologic section, sedimentological, geochemical, and MS properties can be described as follows.

The substrate sediment comprising fine sand and coarse-grained silt with substantial carbonate, soluble magnesium, and calcium, and low clay and organic content, between 8 and $10 \mathrm{~m}$, was deposited at the end of the Ice Age (no radiocarbon dating so far). Based on the geologic data from the study area (Franyó 1966; Rónai 1985; Sümegi et al. 2000), this sediment complex was likely to have been deposited by the Sajó-Hernád river system, supposedly during the Marine Isotope Stage (MIS) 3 period. The sediment also contained iron-manganese nodules. This is likely the cause of the increased level of soluble iron and manganese in the sediment, and the increased MS level (Fig. 8) experienced.

The top layer of the fluvial sediment complex (between 7.8 and $8.0 \mathrm{~m}$ ) consists of very fine and carbonated fine sand mixed with a substantial level of medium-grained sand. This structure and sediment content indicates that this layer was also deposited by the Sajó-Hernád river system that was still present in the Hortobágy during the MIS3 period (Franyó 1966).

On top of this accumulated fluvial sediment, another type of yellow-brown, loesslike alluvial sediment was deposited at the end of the Ice Age between 7.8 and $5.8 \mathrm{~m}$. It is rich in silt, carbonate, and clay. This depositional process was likely to have taken place between $24.5 \mathrm{k}$ and $12 \mathrm{k}$ years cal BP, thus fully covering the MIS2 period. This sediment layer and its development are comparable to the alluvial sediment layers of the Ice Age that developed on river banks in the Hortobágy, previously called infusion loess layer (Nyilas and Sümegi 1991; Sümegi 2005; Sümegi et al. 2015b).

This silt-rich alluvial sediment that had accumulated until the end of the Ice Age can be considered the base rock of soil development in the Holocene, from the Early Holocene to the Early Copper Age (9,500-4,200 cal BC). This type of soil is of 
polygonal structure with hydromorphic qualities that is very similar to A and B layers of the meadow chernozem soil that was found between 4.15 and $5.8 \mathrm{~m}$ buried in the kurgan. The organic content is significantly higher in this horizon (Fig. 8), also showing a change in soluble elements and insignificant level of carbonate content.

The first sign of perturbation of this (first artificially piled) soil layer could be traced between 4.15 and $4.10 \mathrm{~m}$, that is the Late Copper Age. The follow-up research will be targeted at the radiocarbon measurement of this very horizon. On the other hand, this layer is between the Early Copper Age and the second perturbation (artificially piled) layer, i.e., 2.90 and $2.80 \mathrm{~m}$. Based on radiocarbon analysis, the age of the second artificially piled layer is estimated at $4,849 \pm 21$ cal BP $(2,921-2,879$ cal BC), so the first artificial pile of 4.15-4.10 m was very likely built in an earlier horizon, but still in the Late (very end of the) Copper Age (Vaday 2004). Yet another perturbation was traced at $1.50 \mathrm{~m}$, as the coring yielded substantial amounts of pottery and wattle-anddaub fragments from this layer. This finding was insufficient for proper archeological dating, and thus for the chronology of the perturbation layer, but most probably they are from a Scythian or Sarmatian community.

There followed a significant change of the sedimentological and geochemical properties of the kurgan soil, as the development of the top $150 \mathrm{~cm}$ of soil is completely different from the artificially laid ones. The geochemical properties and the development features indicate that after the construction of the kurgan in the Late Copper Age, a new layer of top chernozem soil (with A and B layers) developed on top of the dry earth pile of the kurgan. This is in line with earlier pedological and sedimentological observations made on other kurgans of the Hortobágy and Nagykunság (Sümegi 1992; Barczi et al. 2003, 2004, 2006; Joó et al. 2007; Sümegi and Szilágyi 2011; Szilágyi et al. 2013), namely that chernozem soil has developed on top of the artificial pile of kurgans. This type of top soil and related loess grassland association (Salvio nemorosae-Festucetum rupicolae) form the topmost layer of the kurgan.

\section{Discussion}

The study was carried out on the Ecse Mound, situated on the border of the settlements of Karcag and Kunmadaras. An undisturbed core drilling was carried out, and the sedimentological properties of both the mound and of the substrate baserock were revealed. The sediment series of the substrate comprised fluvial sand and silt layers, while a loess-like alluvial layer topped the series of fluvial sediments between the MIS3 and MIS1 levels. A polyhedral, hydromorphic (chernozem-like) soil layer developed from the beginning of the Holocene until the Copper Age, and a kurgan with at least two artificially piled layers was constructed by the community of the Pit Grave (Yamna) Culture at the end of the Copper Age. As the AMS study indicated, the second artificially piled layer was completed at the end of the Copper Age, more precisely in the period of $4,849 \pm 21 \mathrm{cal} \mathrm{BP}(2,921-2,879$ cal BC). The AMS analysis 
has proved that the date of origin of the Ecse Mound is the Late Copper Age, i.e., the first infiltration of the Yamna (Pit Grave or Ochre Grave) Culture. As comparative chronology for the Copper Age and archeostratigraphic analyses have indicated, this classic Yamna A Horizon of the Late Copper Age is parallel with, and comparable to, the classic Baden Culture elsewhere in Hungary (Horváth et al. 2006).

While the first artificially piled layer requires further radiocarbon measurements, the stratigraphic properties indicate that it was also constructed at the end of the Copper Age. Traces of perturbation were identified from more recent layers dating back to the Stone Age or the Antiquity, and the undisturbed core samples have proved that the topsoil of chernozem developed in-situ after the construction of the kurgan, as a similar process has taken place on other kurgans in the Hortobágy and Nagykunság (Sümegi 1992; Barczi et al. 2003, 2004, 2006; Joó et al. 2007; Sümegi and Szilágyi 2011; Szilágyi et al. 2013).

This research can be considered as the first phase of a long-term program on the scientific research of kurgans. Thus, the methodology of sampling and analysis was fundamentally based on the results and conclusions gained in Quaternary paleoecological and archeogeologic studies in Hungary and abroad (Sümegi 2001, 2002, 2003). It is worth noting that fine stratigraphic sampling was already used in the 1950 s in Quaternary paleoecological and archeogeologic studies internationally, as well as in Hungary (Hokr 1951; Kretzoi 1953, 1957; Kriván 1955; Stieber 1956; Vértes et al. 1956; Krolopp 1961; Jánossy 1962, 1979; Jánossy and Kordos 1976; Kordos 1983; Sümegi 2001, 2002, 2003).

These results clearly show that the methodology reintroduced by the representatives of the so-called landscape ecology (Barczi and Joó 2003, 2009; Barczi 2004; Barczi et al. 2009, 2011, 2012; Petö and Barczi 2011; Tóth et al. 2014, 2015) is a regressive approach, since sediment samples are taken only from the visually distinct macroscopic soil layers. As most scientists (Cushing and Wright 1967; Jánossy 1979; Horáček and Ložek 1988) studying Quaternary objects, including archeological ones, have concluded that sampling from only macroscopic layers will yield skewed results. This statement is even more valid in the case of such an archeological object as an earthen pyramid (kurgan, burial mound) having been piled up of soil. However, the level of elements and carbon must have changed considerably during the soil development process, and later due to ground water table fluctuations and precipitation percolating into the soil.

It must be considered that postgenetic influences, like carbonate movements, or secondary soil formation, can easily cover the real characteristics of the original soil content. By the individual sampling of soil layers, one will gain only a pool of data, but hardly with any trend. Thus, the analysis and interpretation of these data are highly problematic, as nothing more can be scientifically concluded other than that the layers are different, which is already obvious from the macroscopic examination. This method does not allow statistical analysis, and does not inform the results of research on the genetics and precise stratification of layers. To avoid all these mistakes, all sections and core samples were analyzed in 2-4 cm sections with fine stratigraphic methods. 


\section{Conclusions}

The mound that was the object of the study is situated in the Hortobágy in a diversified geomorphological environment predominated by hydromorphic chernozem soil types, and a mosaic of marshland, alkaline, and loess steppe vegetation. The study began by taking large-diameter core samples on a cold winter day, under pollen-free conditions. The $10-\mathrm{m}$ core sample gave a panoramic view of all strata of the mound and the substrate. The radiocarbon measurements and dating have revealed the history of the environment. The baserock formation during the Ice Age was followed by soil development in the Holocene, while the mound was constructed at the end of the Copper Age by the communities of the Pit Grave (Yamna or Ochre Grave) Culture. At least two layers of piled up soil have been identified. While dating of the construction layers needs to be further refined by the AMS analysis (under preparation) of organic remains preserved in the particular layers, it is already certain that both of the construction layers were piled up at the end of the Copper Age.

This study can be considered as a pilot research one, aiming for a much larger-scale scientific program, with the objective of studying kurgans by the means of undisturbed core sampling. The ongoing AMS analyses are amended with phytolith, pollen, malacological, and micromorphological investigations. The results are to be summarized in a publication on the environment and construction of kurgans. Since the results of this preliminary research are in line with earlier kurgan studies, publishing these results is already worthwhile. By publishing these preliminary data, we also wanted to draw attention to the need of concentrated and focused research efforts, and of using standardized methodology in kurgan research, so that the results from different studies performed by different research groups are consistent and comparable. At present, comparative studies are virtually impossible, not only due to the different drilling and sampling techniques, but also because of the lack of standardized methodology in fine stratigraphy and a common understanding of geology, paleoecology, and geo-archeology.

\section{Acknowledgements}

The authors would like to thank Balázs Pál Sümegi and Tünde Törőcsik for assisting in the sedimentological and magnetic susceptibility measurements, as well as Dr. Dávid Gergely Pál for assisting in the geochemical measurements. They would also like to express their special thanks to the Hortobágy National Park Directorate for the financial support provided.

\section{References}

An, Z., G.J. Kukla, S.C. Porter, J. Xiao 1991: Magnetic susceptibility evidence of monsoon variation on the Loess Plateau of central China during the last 130,000 years. - Quaternary Research, 36, pp. 29-36. 
Balázs, R. 2006: Experiences of mound survey in the Kiskunság National Park. - In: Kiss, A., G. Mezősi, Z. Sümeghy (Eds): Táj, környezet és társadalom [Landscape, Environment, Society]. SZTE Éghajlattani és Tájföldrajzi Tanszék, Szeged, pp. 69-77. (in Hungarian)

Balázs, R., R. Kustár 2012: Halmok az évszázadok sodrában. Halmok-hegyek-várak a Duna-Tisza közén [Mounds Over the Centuries. Mounds-Mountains-Castles]. - Kiskunsági Nemzeti Park Alapítvány, Kecskemét, 66 p. (in Hungarian)

Barczi, A. 2004: The importance of pedological investigations in Holocene palaeoecological reconstructions. - Antaeus, 27, pp. 129-134.

Barczi, A., T. Bucsi, C. Centeri, K. Joó, Á. Kenéz, Á. Pető, D. Saláta 2011: Földtan és talajtan [Geology and pedology]. - University course book, Szent István Egyetem, Gödöllő. (in Hungarian)

Barczi, A., K. Joó 2003: A hortobágyi Csípő-halom morfológiai és talajtani elemzése [Pedological studies on Csípõ-halom (mound) in Hortobágy (Hungary)]. - Földrajzi Értesítő, 52, pp. 37-45. (in Hungarian)

Barczi, A., K. Joó 2009: The role of Kurgans in the palaeopedological and palaeoecological reconstruction of the Hungarian Great Plain. - Zeitschrift für Geomorphologie, 53, pp. 131-137.

Barczi, A., T. Horváth, Á. Pető, J. Dani 2012: Hajdúnánás-Tedej-Lyukas-halom: egy alföldi kurgán régészeti értékelése és természettudományos vizsgálata [Hajdúnánás-Tedej-Lyukas-halom: archaeological assessment and scientific examination of a typicalkurgan from the Great Hungarian Plain]. - In: Kreiter, A., Á. Pető, B. Tugya (Eds): Környezet-Ember-Kultúra: Az Alkalmazott Természettudományok és a Régészet Párbeszéde [Environment-Human-Culture: Dialogue Between Applied Sciences and Archaeology]. Magyar Nemzeti Múzeum Nemzeti Örökségvédelmi Központ, Budapest, pp. 25-45. (in Hungarian)

Barczi, A., P. Sümegi, K. Joó 2003: Adatok a Hortobágy paleoökológiai rekonstrukciójához a Csípő-halom talajtani és malakológiai vizsgálata alapján [Data for the palaeoecological reconstruction of the Hortobágy based on pedological and malacological studies made on the Csípő mound]. - Földtani Közlöny, 133/3, pp. 421-432. (in Hungarian)

Barczi, A., P. Sümegi, K. Joó 2004: Adatok a Hortobágy paleoökológiai rekonstrukciójához a Csípő-halom talajtani és malakológiai vizsgálata alapján [Data for the palaeoecological reconstruction of Hortobágy on the basis of the pedological and malacological analysis of Csípö-halom]. - In: Tóth, A. (Ed): A kunhalmokról más szemmel [Mounds in an Other Perspective]. Alföldkutatásért Alapítvány, Kisújszállás/Debrecen, pp. 13-25. (in Hungarian)

Barczi, A., Cs. Tóth, A. Tóth, A. Pető 2009: Bán-halmon komplex tájökológiai és paleotalajtani felmérése [Survey of the biotical and abiotical landscape factors of the Bán-halom kurgan and its surrounding territory]. - Tájökológiai Lapok, 7, pp. 191-208. (in Hungarian)

Barczi, A., T. M. Tóth, A. Csanádi, P. Sümegi, I. Czinkota 2006: Reconstruction of the paleo-environment and soil evolution of the Csípö-halom kurgan, Hungary. - Quaternary International, 156-157, pp. 49-59.

Bede, Á., A.I. Csathó, P. Czukor, D.G. Páll, G. Szilágyi, P. Sümegi 2014: A hortobágyi Ecse-halom geomorfológiai, tájtörténeti, botanikai, szedimentológiai és mikromorfológiai vizsgálatának előzetes eredményei [Previous results of the geomorphological, landscape historical, botanical, sedimentological and micromorphological analyses of the Ecse-mound in Hortobágy]. - In: Sümegi, P. (Ed): Környezetföldtani és környezettörténeti kutatások a dunai Alföldön [Environment Geological and Environment Historical Research in the Great Hungarian Plain Along the Danube River]. GeoLitera, Szeged, pp. 29-41. (in Hungarian)

Bede, Á., A.I. Csathó, P. Czukor, P. Sümegi 2016: Actual botanical survey of an interdisciplinary research at the Ecse-halom kurgan in Hortobágy, Hungary. - In: Barina, Z., K. Buczkó, L. Lőkös, B. Papp, D. Pifkó, E. Szurdoki (Eds): Book of Abstracts. 11th International Conference "Advances in research on the flora and vegetation of the Carpatho-Pannonian region”. Magyar Természettudományi Múzeum, Budapest, pp. 127-129.

Bede, Á., P. Czukor 2015: A Körös-Maros Nemzeti Park Kígyósi-puszta törzsterületén található halmok állapotfelmérése, tájtörténeti leírása és helyreállítási javaslata. Kutatási jelentés [Review, landscape history of and restoration proposal for the mounds in the Kígyósi-puszta reference area of the Körös-Maros National Park. Research report]. - Manuscript, Körös-Maros National Park Directorate, Research Library, Szarvas, 1222, 170 p. (in Hungarian) 
Bede, Á., R.B. Salisbury, A.I. Csathó, P. Czukor, D.G. Páll, G. Szilágyi, P. Sümegi 2015: Report of the complex geoarcheological survey at the Ecse-halom kurgan in Hortobágy, Hungary. - Central European Geology, 58, pp. 268-289.

Benedek, G., M. Zádor-Zsoldos 1998: Jász-Nagykun-Szolnok megyei oklevelek [Diplomas of Jász-Nagykun-Szolnok county]. 1075-1526. - Jász-Nagykun-Szolnok Megyei Levéltár közleményei, 3,320 p. (in Hungarian)

Birks, H.J.B., H.H. Birks 1980: Quaternary Paleoecology. - Edward Arnold Press, London, 289 p.

Bohn, U., N. Zazanashvili, G. Nakhutsrishvili 2007: The map of the natural vegetation of Europe and its application in the Caucasus Ecoregion. - Bulletin of the Georgian National Academy of Sciences, 175, pp. 112-121.

Borhidi, A. 1956: Die Steppen und Wiesen im Sandgebiet der Kleinen Ungarischen Tiefebene. - Acta Botanica Academicae Scientiarium Hungaricae, 2, pp. 241-274.

Borhidi, A. 2003: Magyaroszág Növénytársulásai [Plant Associations of Hungary]. - Akadémiai Kiadó, Budapest, 569 p. (in Hungarian)

Borsy, Z. 1968: Geomorfológiai megfigyelések a Nagykunságban [Geomorphological observations in the Nagykunság region]. - Földrajzi Közlemények, 2, pp. 129-151. (in Hungarian)

Bukovszki, J., Cs. Tóth 2008: Changes in the state of Cumanian mounds lying in the vicinity of Karcag from the end of the 18th century till today. - Acta Geographica ac Geologica et Meteorologica Debrecina, 3, pp. 145-153.

Csathó, A.I. 2009: A mezsgyék természetvédelmi jelentősége és védelmük időszerüsége [Significance and timeliness for nature conservation of the verges]. - Természetvédelmi Közlemények, 15, pp. 171-181. (in Hungarian)

Csathó, A.I., Á. Bede, B. Sudnik-Wójcikowska, I. Moysiyenko, I. Dembicz, J. Sallai-Kapocsi 2015: A szagtalan rezeda (Reseda inodora Rchb.) előfordulása a Tiszántúlon [Reseda inodora Rchb. in the Tiszántúl region (East Hungary)]. - Kitaibelia, 20, pp. 48-54. (in Hungarian)

Cushing, E.J., H.E. Wright 1967: Quaternary palaeoecology. - Yale University Press, New Haven, 433 p.

Dani, J., T. Horváth 2012: Öskori kurgánok a magyar Alföldön. A Gödörsíros (Jamnaja) entitás magyarországi kutatása az elmúlt 30 év során. Áttekintés és revízió. [Prehistoric Kurgans in the Great Hungarian Plain. The Research of the Gödörsíros (Jamnaja) Entity in Hungary Over the Past 30 Years. An Overview and Revision]. - Archaeolingua Alapítvány, Budapest, 215 p. (in Hungarian)

Dániel, P. 2004: Methods of the five-step extraction-digestion method. Results of the five-step extractiondigestion method. - In: Sümegi, P., S. Gulyás (Eds): The Geohistory of Bátorliget Marshland. Archaeolingua Press, Budapest, pp., 53-56, 98-108.

Deák, B., P. Török, B. Tóthmérész, O. Valkó 2015: Mondró-halom kurgan (Hencida, East Hungary), a refugium of loess grassland vegetation. - Kitaibelia, 20, pp. 143-149.

Deák, B., B. Tóthmérész, O. Valkó, B. Sudnik-Wójcikowska, I.I. Moysiyenko, T.M. Bragina, I. Dembicz, P. Török 2016: Cultural monuments and nature conservation: A review of the role of kurgans in the conservation and restoration of steppe vegetation. - Biodiversity and Conservation, 25, pp. 2473-2490.

Dean, W.E., Jr. 1974: Determination of carbonate and organic matter in calcareous sediments and sedimentary rocks by loss on ignition: Comparison with other methods. - Journal of Sedimentary Research, 44, pp. 242-248.

Dearing, J. 1994: Environmental Magnetic Susceptibility. Using the Bartington MS2 System. Chi Publishing, Kenilworth, 104 p.

Demkin, V.A., V.M. Klepikov, S.N. Udaltsov, T.S. Demkina, M.V. Eltsov, T.E. Khomutova 2014: New aspects of natural science studies of archaeological burial monuments (kurgans) in the southern Russian steppes. - Journal of Archaeological Science, 42, pp. 241-249.

Dengler, J., M. Janišová, P. Török, C. Wellstein 2014: Biodiversity of Palaearctic grasslands: A synthesis. Agriculture, Ecosystems \& Environment, 182, pp. 1-14.

Ecsedy, I. 1973: Újabb adatok a Tiszántúl rézkori történetéhez [New data on the history of the Copper Age in the region beyond the Tisza]. - A Békés Megyei Múzeumok Közleményei, 2, pp. 3-40. (in Hungarian) 
Ecsedy, I. 1979: The People of the Pit-Grave Kurgans in Eastern Hungary. - Fontes Archaeologici Hungaricae, Akadémiai Kiadó, Budapest, 147 p.

Elek, G. 2008: Várostörténet ötvenkét tételben. Karcag város története 1506-1950 között [City History in Fifty-Two Theses. History of Karcag City Between 1506 and 1950]. - Karcagi Nyomda Kft., Karcag, 199 p. (in Hungarian)

Forchhammer, G., J. Steenstrup, J. Worsaae 1851: Undersøgelser i geologisk-antiqvarisk Retning (Særskilt optrykt af Oversigten over Videnskabernes Selskabs Forhandlinger i Aarene 1848 og 1851) [Exposures in Geological-Antique Direction (Specially Reprinted by the Summary of Science Society's Discussions in 1848 and 1851)]. - Bianco Luno's Bogtrykkeri, Kjøbenhavn, 57 p. (in Danish)

Franyó, F. 1966: A Sajó-Hernád hordalékkúpja a negyedkori földtani események tükrében (Der Schwämmfächer der Flüsse Sajó und Hernád im Spiegel der geologischen. Ereignisse des Quartärs) [Alluvial cone of the Sajó and Hernád Rivers in the view of the geological event of the Quaternary Period]. - Földrajzi Értesítö, 15, pp. 153-178. (in Hungarian)

Fuchs, M. 2012: Nagy duzzadó agyagtartalmú talajok osztályozásának diagnosztikai szemléletü korszerüsítése [Diagnostic modernization of soil classification containing high swelling clays]. - PhD Thesis, Szent István Egyetem, Gödöllő. (in Hungarian)

Gárdonyi, N.G. 1893: A régi kunok temetkezése [Burial of old kuns]. - Archaeologiai Értesítô, 13, pp. 105-117. (in Hungarian)

Gárdonyi, N.G. 1914: A magyarországi halmok kérdéséhez [To the question of Hungarian mounds]. Archaeologiai Értesítő, 34, pp. 381-394. (in Hungarian)

Gazdapusztai, Gy. 1968: Chronologische Fragen in der Alfölder Gruppe der Kurgan-Kultur [Chronological questions in the Kurgan Culture group of the Great Hungarian Plain]. - Móra Ferenc Múzeum Évkönyve, 2, pp. 91-100.

Gimbutas, M. 1980: The kurgan wave 2 into Europe and the following transformation of culture. - Journal of Indo-European Studies, 8, pp. 273-317.

Gulyás, S., P. Sümegi, M. Molnár 2010: New radiocarbon dates from the Late Neolithic tell settlement of Hódmezővásárhely-Gorzsa, SE Hungary. - Radiocarbon, 52, pp. 1458-1464.

Gyárfás, I. 1870: Valami a kunhalmokról [Something about mounds]. - Archaeologiai Értesítő, 3, pp. 3342. (in Hungarian)

Gyárfás, I. 1883: A jász-kunok története. III.: 1301-1542 [History of Jases III: 1301-1542]. - Bakos István Nyomda, Szolnok, 582 p. (in Hungarian)

Győrffy, I. 1821: Kúnhalmok és telephelyek a karczagi határban [Kurgans and sites in the border of Karcag]. Föld és ember, 1, pp. 59-62. (in Hungarian)

Gyucha, A., G. Bácsmegi, O. Fogas, W.A. Parkinson 2006: House construction and settlement patterns on an Early Copper Age site in the Great Hungarian Plain. - Communicationes Archaeologicae Hungariae, 2006, pp. 5-28.

Gyucha, A., W.A. Parkinson, R. Yerkes 2004: Kora rézkori településkutatás az Alföldön. Előzetes jelentés a Körös regionális régészeti program 1998-2002 között végzett munkájáról [Early Copper Age settlement research in the Great Hungarian Plain. Preliminary report on the work of the Körös Regional Archaeological Program between 1998 and 2002]. - Móra Ferenc Múzeum Évkönyve, Studia Archaeologica, 10, pp. 25-52. (in Hungarian)

Hertelendi, E., É. Csongor, L. Záborszky, I. Molnár, I. Gál, M. Győrffy, S. Nagy 1989: Counting system for high precision C-14 dating. - Radiocarbon, 32, pp. 399-408.

Hertelendi, E., P. Sümegi, G. Szöör 1992: Geochronologic and paleoclimatic characterization of Quaternary sediments in the Great Hungarian Plain. - Radiocarbon, 34, pp. 833-839.

Hokr, A. 1951: A method of the quantitative determination of the climate in the Quaternary Period by means of mammal associations. - Sborník ústředního ústavu geologický, oddíl paleontologický, 18, pp. 209-219.

Horáček, I., V. Ložek 1988: Paleozoology and the Mid-European Quaternary past: Scope of the approach and selected results. - Rozpravy Československé akademie věd, Řada matematických a přírodovědných věd, 98/4, pp. 3-102. 
Horvát, I. 1825: Rajzolatok a magyar nemzet legrégibb történetéből [Sketches from the most ancient period of the history of the Hungarian nation]. - Petrózai Trattner Mátyás Kiadó, Pest, 162 p. (in Hungarian)

Horváth, T., J. Dani, Á. Pető, Ł. Pospieszny, É. Svingor 2013: Multidisciplinary contributions to the study of Pit Grave culture kurgans of the Great Hungarian Plain. - In: Heyd, V., G. Kulcsár, V. Szeverényi (Eds): Transitions to the Bronze Age: Interregional Interaction and Socio-Cultural Change in the Third Millennium BC Carpathian Basin and Neighbouring Regions (No. 30). Archaeolingua Kiadó, Budapest, pp. 153-180.

Horváth, A., E. Illyés, Z. Molnár, C. Molnár, A.I. Csathó, S. Bartha, A. Kun, I.J. Türke, I. Bagi, J. Bölöni 2011: Löszgyepek, kötött talajú sztyeprétek [Closed steppes on loess]. - In: Bölöni, J., Z. Molnár, A. Kun (Eds): Magyarország élőhelyei. Vegetációtípusok leírása és határozója [Habitats of Hungary. Description and Definition of Vegetation Types]. ÁNÉR 2011. MTA Ökológiai és Botanikai Kutatóintézete, Vácrátót, pp. 174-181. (in Hungarian)

Horváth, T., É. Svingor, M. Molnár 2006: Újabb adatok a Baden-péceli kultúra keltezéséhez [New data on the formation of the Baden Pécel culture]. - Archeometriai Mühely, 2006/3, pp. 19-30. (in Hungarian)

Illyés, E., J. Bölöni 2007: Löszsztyeppek, lejtőssztyeppek és erdőssztyepp rétek Magyarországon [Loess steppe, slope steppe and forest-steppe meadows in Hungary]. - Private Edition, Budapest. (in Hungarian)

Jánossy, D. 1962: Vorläufige Ergebnisse der Ausgrabungen in der Felsnische Rejtek 1. - Karszt- és Barlangkutatás, 3, pp. 49-57.

Jánossy, D. 1979: A Magyarországi Pleisztocén Tagolása Gerinces Faunák Alapján [Pleistocene Vertebrate Faunas of Hungary]. - Akadémiai Kiadó, Budapest, 206 p. (in Hungarian)

Jánossy, D., L. Kordos, 1976: Pleistocene-Holocene mollusc and vertebrate fauna of two caves in Hungary. - Annales Historico-Naturales Musei Naturalis Hungarici, 68, pp. 5-29.

Jefferson, T. 1783: Notes of the State of Virginia.- Prichard and Hall, Philadelphia, 244 p.

Jerney, J. 1851: Jerney János' keleti utazása a 'magyarok' őshelyeinek kinyomozása végett 1844 és 1845 [Eastern journey of János Jerney in order to find the ancestors of Hungarians 1844 and 1845] (I-II). Private Edition, Pest, 644 p. (in Hungarian)

Joó, K. 2003: Kunhalom kutatások (A Csípő-halom vegetációja) [Researches on kurgans (The vegetation of Csípő Mound)]. - Tájökológiai Lapok, 1, pp. 87-96. (in Hungarian)

Joó, K., A. Barczi, P. Sümegi 2007: Study of soil scientific, layer scientific and palaeoecological relations of the Csípő-mound kurgan. - Atti della Societa Toscana di Scienze Naturali, A112, pp. 141-144.

Kashirskaya, N.N., T.E. Khomutova, V.V. Dmitriev, V.I. Duda, N.E. Suzina, V.A. Demkin 2010: The morphology of cells and the biomass of microorganisms in the buried paleosols and modern steppe soils of the Lower Volga region. - Eurasian Soil Science, 43, pp. 1140-1149.

Kelemen, A., P. Török, B. Deák, O. Valkó, B.A. Lukács, S. Lengyel, B. Tóthmérész 2010: Spontán gyepregeneráció extenzíven kezelt lucernásokban [Spontaneous grassland regeneration in extensively managed alfalfa fields]. - Tájökológiai Lapok, 8, pp. 33-44. (in Hungarian)

Khomutova, T.E., T.S. Demkina, A.V. Borisov, N.N. Kashirskaya, M.V. Yeltsov, V.A. Demkin 2007: An assessment of changes in properties of steppe kurgan paleosoils in relation to prevailing climates over recent millennia. - Quaternary Research, 67, pp. 328-336.

Kőhegyi, M., G. Vörös 1999: A vaskúti halmok és földvár (Kutatástörténet és anyagközlés) [Die Hügel und der Erdwall von Vaskút (Forschungsgeschichte und Materialvorlage)] [The kurgans and earth fort of Vaskút (Research history and presentation of findings)]. - Studia Archaeologica, 5, 217-259.

Köhegyi, M., G. Vörös 2000: Die Forschungsgeschichte der Hügel und des Erdwalles von Vaskút [History of the research of the kurgans and earth fort of Vaskút]. - Acta Archaeologica Academiea Scientiarum Hungaricae, 51, pp. 327-339.

Kőhegyi, M., G. Vörös 2002: A vaskúti szarmata kori halomsírok [Sarmatian kurgans of Vaskút]. Múzeumi kutatások Csongrád megyében, 2001, pp. 5-11.(in Hungarian)

Konert, M., J. Vandenberghe 1997: Comparison of layer grain size analysis with pipette and sieve analysis: A solution for the underestimation of the clay fraction. - Sedimentology, 44, pp. 523-535.

Kordos, L. 1983: Palaeclimatologic and biostratigraphic studies in Holocene small mammals. - Geologische Jahrbuch, A71, pp. 339-359. 
Kovács, M. 2013: Az Ecse-halom komplex földrajzi vizsgálata és bemutatása [Complex geographical analysis and presentation of Ecse mound]. - Természet Világa, 144, pp. 79-82. (in Hungarian)

Kováts, G. 1784-1787: Geometrica delineatio totius terreni privilegiati oppidi cumanicalis Kartzag Uj Szállás, 1:40, 000 [Geometrical delineation of the territory of the privileged Cumanian city of Kartzag Uj Szállás, 1:40, 000]. - Jász-Nagykun-Szolnok Megyei Levéltár térképtára, T.300. (in Hungarian)

Kretzoi, M. 1953: A negyedkor taglalása gerinces faunák alapján [Quaternary on the basis of vertebrata fauna]. - MTA Müszaki Tudományos Osztályának Alföldi Kongresszusa, Budapest, pp. 89-99. (in Hungarian)

Kretzoi, M. 1957: Wierbeltierfaunistische Angaben zur Quartärchronologie der Jankovich Höhle [Data on the vertebrate fauna of the Jankovich Cave to support its quaternary chronology]. - Folia Archeologica, 9, pp. 16-21.

Kriván, P. 1955: A közép-európai pleisztocén éghajlati tagolása [Climate of the Central European Pleistocene]. - Annales of the Geological Institute of Hungary, 43, pp. 363-503. (in Hungarian)

Krolopp, E. 1961: A Buda környéki alsó-pleisztocén mésziszapok csigafaunájának állatföldrajzi és ökológiai vizsgálata [Animal Geographical and Ecological Analysis of the Snail Fauna of the Lower Pleistocene Lime in Buda]. - Doctoral Thesis, Budapest. (in Hungarian)

Kulcsár, V. 1989: Rómer Flóris és a vaskúti földépítmények [Flóris Rómer and the ground constructions of Vaskút]. - Cumania, 11, pp. 149-152. (in Hungarian)

Liritzis, I., A.K. Singhvi, J.K. Feathers, G.A. Wagner, A. Kadereit, N. Zacharias, S.H. Li 2013: Luminescence Dating in Archaeology, Anthropology, and Geoarchaeology: An Overview. - Springer, Heidelberg, $70 \mathrm{p}$.

Lomov, S.P., A.V. Lyganov, A.A. Khisyametdinova, I.N. Spiridonova, N.N. Solodkov 2017: Modern and buried soils of kurgans in the forest-steppe zone of the Middle Volga region (by the example of Komintern I kurgan). - Eurasian Soil Science, 50, pp. 539-548.

Makkay, J. 1964: Megjegyzések Gunda Béla: az aterrado-müvelés és az alföldi kunhalmok kérdése c. cikkéhez [Notes to Gunda Béla's article: Aterrado cultivation and kurgans of the Great Hungarian Plain]. - Ethnográfia, 75, pp. 471-474. (in Hungarian)

Merpert, N.Y. 1974: Drevneishije skotovody volzhsko-uralskogo mezhdurechja [The Most Ancient CattleBreeders in the Volga-Ural Steppes]. - Nauka, Moscow, 151 p. (in Russian)

Michéli, E., M. Fuchs, T. Szegi, G. Kele, M. Vajdulák 2005: Nagy duzzadó agyagtartalmú talajok osztályozásának diagnosztikai szemléletü korszerüsítése [Diagnostic Modernization of Soil Classification Containing High-Swelling Clays]. - Talajvédelem, Special Issue, Talajvédelmi Alapítvány, Budapest, pp. 278-281. (in Hungarian)

Minasny, B., A.B. Mcbratney, A.E. Hartemink 2009: Global pedodiversity, taxonomic distance and the World Reference Base. - Geoderma, 155, pp. 132-139.

Molnár, M., K. Joó, A. Barczi, Z. Szántó, I. Futó, L. Palcsu, L. Rinyu 2004: Dating of total soil organic matter used in kurgan studies. - Radiocarbon, 46, pp. 413-419.

Molnár, M., L. Rinyu, M. Veres, M. Seiler, L. Wacker, H. Synal 2013: EnvironMICADAS: A mini 14C AMS with enhanced gas ion source interface in the Hertelendi Laboratory of Environmental Studies (HEKAL), Hungary. - Radiocarbon, 55/2, pp. 228-244.

Molnár, M., É. Svingor 2011: An interpretation of the soil 14C results of the Hajdúnánás-Tedej-Lyukashalom kurgan. - In: Pető, Á., A. Barczi (Eds): Kurgan Studies: An Environmental and Archaeological Multiproxy Study of Burial Mounds in the Eurasian Steppe Zone. Archaeopress, Oxford, pp. 255-258.

Molnár, Z., M. Biró, S. Bartha, G. Fekete 2012: Past trends, present state and future prospects of Hungarian forest-steppes. - In: Werger, M.J.A., M.A. van Staalduinen (Eds): Eurasian Steppes. Ecological Problems and Livelihoods in a Changing World. Springer, Dordrech, pp. 209-252.

Molnár, Z., A. Horváth, A.I. Csathó, G. Lendvai, S. Bartha 2014: Síksági pannon löszsztyeppek [Pannonian lowland loess steppe]. - In: Haraszthy, L. (Ed): Natura 2000 Fajok és Élőhelyek Magyarországon [Natura 2000 species and habitats in Hungary]. Pro Vértes Közalapítvány, Csákvár, pp. 810-816. (in Hungarian) 
Molnár, Z., A. Kun (Eds) 2000: Alföld erdőssztyepp maradványok Magyarországon [Forest Steppe Remains in the Great Hungarian Plain]. - WWF Publishing, Budapest. (in Hungarian)

Morgunova, N.L., O.S. Khokhlova 2006: Kurgans and nomads: New investigations of mound burials in the southern Ural. - Antiquity, 80, pp. 303-17.

Morgunova, N.L., O.S. Khokhlova 2013: Chronology and periodization of the pit-grave culture in the Region between the Volga and Ural rivers based on radiocarbon Dating and paleopedological research. Radiocarbon, 55, pp. 1286-1296.

Munsell, A.H. 2000: Munsell Soil Color Charts. - Munsell Color Company, Baltimore, 29 p.

Nyilas, I., P. Sümegi 1991: The Mollusc fauna of Hortobágy at the end of the Pleistocene (Würm3) and in the Holocene. - Proceedings of 10th International Malacological Congress, Tübingen, pp. 481-486.

Párducz, M. 1959: Hunkori halmok Vaskút határában [Hun kurgans in the border of Vaskút]. - Folia Archaeologica, 11, pp. 95-104.(in Hungarian)

Parkinson, W.A. 2006: The social organisation of early copper age tribes on the Great Hungarian Plain. British Archaeological Reports, 1573, pp. 123-156.

Pásztor, E. 2004: Útikalauz. Bronzkori, vaskori földvárak és halomsírok a Dunántúlon [Kurgans in Transdanubia from the Bronze and Iron Age]. - Magistratum Stúdió, Kecskemét, 198 p. (in Hungarian)

Penksza, K., T. Kiss, E. Herczeg, A. Nagy, Á. Malatinszky 2011: Anthropogenic impacts and management of natural grasslands on kurgans. - In: Pető, Á., A. Barczi (Eds): Kurgan Studies: An Environmental and Archaeological Multiproxy Study of Burial Mounds in the Eurasian Steppe Zone. British Archaeological Reports, Archaeopress, Oxford, UK, 2238, pp. 329-338.

Persaits, G., P. Sümegi 2011: A fitolitok szerepe a régészeti geológiai és környezettörténeti minták értékelésében [The role of phytoliths in archeogeological and environment historical analysis]. In: Unger, J., E. Pál-Molnár (Eds): Geoszférák 2010 [Geospheres 2010]. GeoLitera, Szeged, pp. 307-354. (in Hungarian)

Persaits, G., S. Gulyás, P. Sümegi, M. Imre 2008: Phytolith analysis: Environmental reconstruction derived from a Sarmatian kiln used for firing pottery. - In: Szabó, P., R. Hédl (Eds): Human Nature: Studies in Historical Ecology and Environmental History. Institute of Botany of the Czech Academy of Sciences, Pruhonice, pp. 116-122.

Persaits, G., P. Sümegi 2015: Régészeti lelőhelyekről származó fitolit vizsgálatok jelentősége az archeobotanikában [The importance of phytolith analysis of archaeological sites in archaeobotany]. In: Törőcsik, T., K. Náfrádi, P. Sümegi (Eds): Komplex archeobotanika [Complex archaeobotany]. GeoLitera, Szeged, pp. 145-154. (in Hungarian)

Persaits, G., P. Sümegi, T. Törőcsik 2014: A solti Tételhegy környezettörténete pollen- és -tolitelemzés alapján [The environmental history of Solt-Tételhegy based on pollen and phytolith analyses]. - In: Somogyvári, Á., J. Szentpéteri (Eds): Településtörténeti kutatások. Solt-Tételhegy, Kiskunfélegyháza, Amler-bánya [Studies on the history of settlements. Solt-Tételhegy, Kiskunfélegyháza, Amler Mine]. Archaeologica Cumania, 3, pp. 159-204. (in Hungarian)

Petö, Á., A. Barczi 2011: Kurgan Studies. An Environmental and Archaeological Multiproxy Study of Burial Mounds in the Eurasian Steppe Zone. - Archaeopress, Oxford, 350 p.

Pigati, J.S., J. Quade, T.M. Shanahan, C.V. Haynes Jr. 2004: Radiocarbon dating of minute gastropods and new constraints on the timing of spring-discharge deposits in southern Arizona, USA. Palaeogeography, Palaeoclimatology, Palaeoecology, 204, pp. 33-45.

Pigati, J.S., J.A. Rech, J.C. Nekola 2010: Radiocarbon dating of small terrestrial gastropod shells in North America. - Quaternary Geochronology, 5, pp. 519-532.

Pigati, J.S., J.P. McGeehin, D.R. Muhs, E.A. Bettis 2013: Radiocarbon dating late Quaternary loess deposits using small terrestrial gastropod shells. - Quaternary Science Reviews, 76, pp. 114-128.

Rachkovskaya, E.I., T.M. Bragina 2012: Steppes of Kazakhstan: diversity and present state. - In: Werger, M.J.A., M.A. van Staalduinen (Eds): Eurasian Steppes. Ecological Problems and Livelihoods in a Changing World. Springer, Dordrech, pp. 103-148.

Raczky, P. 1988: Tiszavidék kulturális és kronológiai kapcsolatai a Balkánnal és az Égeikummal a neolitikum, rézkor időszakában [The Cultural and Chronological Connections of the Tisza Region 
with the Balkan and Aegean at the Time of the Neolithic and Chalcolithic]. - Publication of Szolnok County Museums Directorate and ELTE University, Department of Archaeology, Szolnok. (in Hungarian)

Raczky, P. 1995: New data on the absolute chronology of the Copper Age in the Carpathian Basin. Inventarja Praehistorica Hungariae, 7, pp. 51-60.

Ralska-Jasiewiczowa, M., T. Goslar, K. Różański, A. Wacnik, J. Czernik, L. Chróst 2003: Very fast environmental changes at the Pleistocene/Holocene boundary, recorded in laminated sediments of Lake Gościąż, Poland. - Palaeogeography, Palaeoclimatology, Palaeoecology, 193, pp. 225-247.

Rasmussen, S.O., K.K. Andersen, A.M. Svensson, J.P. Steffensen, B.M. Vinther, H.B. Clausen, S.J. Siggaard-Andersen, L.B. Larsen, D. Dahl-Jensen, M. Bigler, R. Rhöthlisberger, H. Fischer, M.E. Hansson, U. Ruth 2006: A new Greenland ice core chronology for the last glacial termination. - Journal of Geophysical Research: Atmospheres, 111, D06102, doi:10.1029/2005JD006079.

Rassamakin, Y. 1994: The main directions of the development of early pastoral societies of Northern Pontic Zone: 4500-2450 BC (Pre-yamnaya cultures and Yamnaya culture). - Baltic-Pontic Studies, 2, pp. 29-70.

Reimer, P.J., E. Bard, A. Bayliss, J.W. Beck, P.G. Blackwell, C. Bronk-Ramsey, C.E. Buck, H. Cheng, R.L. Edwards, M. Friedrich, P.M. Grootes, T.P. Guilderson, H. Haflidason, I. Hajdas, E.C. Hatt, T.J. Heaton, A.G. Hogg, K.A. Hughen, K.F. Kaiser, B. Kromer, S.W. Manning, M. Niu, R.W. Reimer, D.A. Richards, E.M. Scott, J.R. Southon, C.S.M. Turney, J. van der Plicht 2014: IntCal13 and MARINE13 radiocarbon age calibration curves 0-50000 years calBP. - Radiocarbon, 55, pp. 1869-1887.

Rómer, F. 1868a: Kivonat a m. tud. Akadémiai archaeológiai bizottságának jegyzőkönyvéből. October 6-án tartott VIII. rendes ülésében [Resume of the report of the archaeological committee of the Hungarian Academy of Sciences. $8^{\text {th }}$ meeting held on $6^{\text {th }}$ October]. - Archeológiai Értesítö, 1, pp. 13-14. (in Hungarian)

Rómer, F. 1868b: Kivonat a m. tud. Akadémiai archaeológiai bizottságának jegyzőkönyvéből. Jun. 23-án tartott VI-dik rendes ülésében [Resume of the report of the archaeological committee of the Hungarian Academy of Sciences. $6^{\text {th }}$ meeting held on 23th June]. - Archeológiai Értesítö, 1, pp. 11-12. (in Hungarian)

Rómer, F. 1868c: Kivonat a m tud. Akadémiai archaeológiai bizottságának jegyzőkönyvéből. Július 7-én tartott VII-dik rendes ülésben [Resume of the report of the archaeological committee of the Hungarian Academy of Sciences. $7^{\text {th }}$ meeting held on $7^{\text {th }}$ July]. - Archeológiai Értesítö, 1, pp. 12-13. (in Hungarian)

Rómer, F. 1878: Compte rendu de la huitième session à Budapest 1876. I. Partie: Résultats généreaux. Congrès International d'Anthropologie et d'Archéologie Préhistoriques [Report on the eight session in Budapest, 1876. Part I: International Conference of Anthropology and Prehistoric Archaeology]. Edition du Musée National Hongrois, Budapest, 187 p.

Rónai, A. 1985: Az Alföld földtana [Geology of the Great Hungarian Plain]. - Acta Geologica Hungarica, 21, pp. 1-445. (in Hungarian)

Rousseau, D.D., G. Kukla 1994: Late Pleistocene climate record in the Eustis loess section, Nebraska, based on land snail assemblages and magnetic susceptibility. - Quaternary Research, 42, pp. 176-187.

Stefanovits, P. 1963: Magyarország Talajai. 2. kiadás [The Soils of Hungary] (2nd ed.). - Akadémiai Kiadó, Budapest, 442 p. (in Hungarian)

Stefanovits, P. 1972: Talajtan [Pedology]. - Mezőgazda Kiadó, Budapest, 380 p. (in Hungarian)

Stieber, J. 1956: Anthrakotomische Untersuchung [Anthracological research]. - Folia Archaeologica, 8, pp. 3-11.

Sudnik-Wójcikowska, B., I.I. Moysiyenko 2013: Ukrainian kurgans as refugia of steppe flora and their role in steppe restoration. - In: Baumbach, H., S. Pfützenreuter (Eds): Steppenlebensräume Europas - Gefährdung, Erhaltungsmaßnahmen und Schutz [European Steppe Habitats - Threats, management and protection]. Thüringer Ministerium für Landwirtschaft, Forsten, Umwelt und Naturschutz, Erfurt, pp. 201-210. 
Sudnik-Wójcikowska, B., I.I. Moysiyenko, M. Zachwatowicz, E. Jabłońska 2011: The value and need for protection of kurgan flora in the anthropogenic landscape of steppe zone in Ukraine. - Plant Biosystems, 145, pp. 638-653.

Sun, J., T. Liu 2000: Multiple origins and interpretations of the magnetic susceptibility signal in Chinese wind-blown sediments. - Earth and Planetary Science Letters, 180, pp. 287-296.

Sümegi, P. 1988: Jelentés a Hortobágy-Szálkahalmon végzett geomorfológiai, üledékföldtani és quartermalakológiai vizsgálatokról [Report of the geomorphological, sedimentological and quartermalacological analysis of Hortobágy-Szálkahalom]. - Manuscript, University of Debrecen, Department of Mineralogy and Geology, Debrecen. (in Hungarian)

Sümegi, P. 1992: Jelentés a sárrétudvari Ör-halmon végzett geomorfológiai, üledékföldtani vizsgálatokról [Report of the geomorphological, sedimentological analysis of Ör mound in Sárrét]. - Manuscript, Déri János Museum and University of Debrecen, Department of Mineralogy and Geology. (in Hungarian)

Sümegi, P. 1994-1999: Régészeti geológia hivatalos speciális kollégium előadás és gyakorlat jegyzet- és ábraanyaga [The official notes and figures of archeogeology special course]. - Manuscript, University of Debrecen, Department of Mineralogy and Geology, 211 p. (in Hungarian)

Sümegi, P. 1998: Az utolsó 15000 év környezeti változásai és hatásuk az emberi kultúrákra Magyarországon [Environmental changes and their impact on human cultures in Hungary during the last 15000 years]. In: Ilon, G. (Ed): A régésztechnikusok kézikönyve [Manual for archaeological technicians]. Savaria Múzeum, Szombathely, pp. 367-397. (in Hungarian)

Sümegi, P. 2001: A negyedidőszak földtanának és őskörnyezettanának alapjai [Basics of Quaternary geology and palaeontology]. - JATE Press, Szeged, 262 p. (in Hungarian)

Sümegi, P. 2002: Régészeti geológia és történeti ökológia alapjai [Basics of archaeogeology and historical ecology]. - JATE Press, Szeged, 224 p. (in Hungarian)

Sümegi, P. 2003: Régészeti geológia - tudományos interdiszciplinák találkozása [Archaeogeology encounter of scientific interdisciples]. - Habilitation Thesis, Szegedi Tudományegyetem, Szeged. (in Hungarian)

Sümegi, P. 2004a: Jelentés a sárrétudvari Ör-halmon végzett környezettörténeti vizsgálatok eredményéről [Report of the results of environmental historical analysis of Ör-mound in Sárrétudvar]. - National Research and Development Program Report, University of Szeged, Department of Geology and Palaeontology. (in Hungarian)

Sümegi, P. 2004b: The results of paleoenvironmental reconstruction and comparative geoarcheological analysis for the examined area. - In: Sümegi, P., S. Gulyás (Eds): The Geohistory of Bátorliget Marshland. Archaeolingua Press, Budapest, pp. 301-348.

Sümegi, P. 2005: Loess and Upper Paleolithic environment in Hungary. - Aurea Kiadó, Nagykovácsi, 312 p.

Sümegi, P. 2009: Ember és környezet kapcsolata a középső-bronzkorban: az őskori gazdasági tér fejlődése egy bronzkori tell geoarcheológiai és környezettörténeti feldolgozása nyomán [The relationship of man and environment during the Late Bronze Age: The evolution of a Bronze Age tell on the basis of geoarchaeological and environment historical analysis].- Tisicum, 19, pp. 130-154. (in Hungarian)

Sümegi, P. 2012: Report on the results of the sedimentological survey of the Ecse mound. - Manuscript, Records of Hortobágy National Park Directorate, Debrecen. (in Hungarian)

Sümegi, P. 2013: Comparative geoarcheological report and environmental history of the Bronze Age tell of Polgár-Kenderföld. - In: Vicze, M., I. Poroszlai, P. Sümegi (Eds): Hoard, Phase, Period? Round Table Conference on the Koszider Problem. Matrica Múzeum Kiadványa, Százhalombatta, pp. 155-192.

Sümegi, P., Á. Bede, G. Szilágyi 2015a: Régészeti geológiai, geoarcheológiai és környezettörténeti elemzések régészeti lelőhelyeken-a földtudományok és a régészet kapcsolata [Archaeogeological, geoarchaeological and environment historical analysis in archaeological sites- the relationship of earth sciences and archaeology]. - Archeometriai Műhely, 12, pp. 135-150. (in Hungarian)

Sümegi, P., E. Hertelendi 1998: Reconstruction of microenvironmental changes in Kopasz Hill loess area at Tokaj (Hungary) between 15.000-70.000 BP years. - Radiocarbon, 40, pp. 855-863. 
Sümegi, P., J. Kozák, E. Magyari, Cs. Tóth 1998: A Szakáld-Testhalmi bronzkori tell geoarcheológiai vizsgálata [Geoarchaeological analyses of the Bronze Age tell of Szakáld-Testhalom]. - Acta Geographica, Geologica et Meteorologica Debrecina, 34, pp. 181-202. (in Hungarian)

Sümegi, P., E. Magyari, P. Dániel, M. Molnár, T. Törőcsik 2013b: 28, 000-year record of environmental change in SE Hungary: Terresengtrial response to Dansgaard-Oeshger cycles and Heinrich-events. Quaternary International, 278, pp. 34-50.

Sümegi, P., E. Magyari, Z. Szántó, S. Gulyás, K. Dobó 2002: Man and environment in the Late Neolithic of the Carpathian Basin - A preliminary geoarcheological report of Polgár-Csőszhalom. - In: Aslan, R., S. Blum, G. Kastl, F. Schweizer, D. Thumm (Eds): MauerSchau, 2. Festschrift für Manfred Korfmann. Verlag Bernard Albert Greiner, Remshalden-Grunbach, pp. 838-840.

Sümegi, P., S. Molnár 2007: The Kiritó meander: Sediments and the question of flooding. - In: Whittle, A. (Ed): The Ecsegfalva project. Varia Archaeologica Hungarica, 21, pp. 67-82.

Sümegi, P., S. Molnár, K. Herbich, M. Imre, G. Szegvári, S. Gulyás, G. Timár 2013a: Late Neolithic man and environment in the Carpathian Basin: A preliminary geoarcheological report from Csőszhalom at Polgár. In: Baldia, M.O., T.K. Perttula, D.S. Frink (Eds): Comparative archaeology and paleoclimatology. Socio-cultural responses to a changing world. British Archaeological Reports, 2456, pp. 139-145.

Sümegi, P., A. Molnár, G. Szilágyi 2000: Szikesedés a Hortobágyon [Salinization in the Hortobágy]. Természet Világa, 131/5, pp. 213-216. (in Hungarian)

Sümegi, P., K. Náfrádi 2015: A radiocarbon-dated cave sequence and the Pleistocene/Holocene transition in Hungary. - Open Geosciences, 7, pp. 783-798.

Sümegi, P., K. Náfrádi, D. Molnár, S. Sávai 2015b: Results of paleoecological studies in the loess region of Szeged-Öthalom (SE Hungary). - Quaternary International, 372, pp. 66-78.

Sümegi, P., E. Rudner, T. Törőcsik 2012: Magyarországi pleisztocén végi és kora-holocén környezeti változások kronológiai, tér és időbeli rekonstrukciós problémái [Chronological and spatial resonstruction problems of environment changes in Hungary during the Late Pleistocene and Early Holocene]. In: Kolozsi, B. (Ed): Proceedings of the IV. MOMOSZ Meeting of Prehistoric Researchers. Déri János Museum, Debrecen, pp. 279-298. (in Hungarian)

Sümegi, P., G. Szilágyi 2011: A quarter-malacological inventory of Hungarian kurgans. - In: Pető, Á., A. Barczi (Eds): Kurgan Studies: An Environmental and Archaeological Multiproxy Study of Burial Mounds in the Eurasian Steppe Zone. Archaeopress, Oxford, pp. 279-291.

Szabolcs, I. 1966: A genetikus üzemi talajtérképezés módszerkönyve [Methods of genetic soil mapping]. OMMI, Budapest, 428 p. (in Hungarian)

Szelepcsényi, Z., H. Breuer, A. Kis, R. Pongrácz, P. Sümegi 2018: Assessment of projected climate change in the Carpathian Reigon using the Holdridge life zone system. - Theoretical and Applied Climatology, 31, pp. 1-18.

Szelepcsényi, Z., H. Breuer, P. Sümegi 2014a: Hogyan változtak a Kárpát-medence régiójának életzónái a múlt században? [How did the lifestyle of the Carpathian Basin region change in the last century?]. In: Sümegi, P. (Ed): Környezetföldtani és környezettörténeti kutatások a dunai Alföldön. GeoLitera Kiadó, Szeged, pp. 163-172. (in Hungarian)

Szelepcsényi, Z., H. Breuer, P. Sümegi 2014b: The climate of Carpathian Region in the 20th century based on the original and modified Holdridge life zone system. - Central European Journal of Geosciences, 6/3, pp. 293-307.

Szilágyi, G., P. Sümegi, D. Molnár, S. Sávai 2013: Mollusc-based paleoecological investigations of the Late Copper-Early Bronze Age earth mounds (kurgans) on the Great Hungarian Plain. - Central European Journal of Geosciences, 5, pp. 465-479.

Szilágyi, M. 2008: Változások az Alföldön az i.e. 5. évezred derekán [Changes in the Great Hungarian Plain in the middle of the 5th millennia]. - Első Század, 2, pp. 361-427. (in Hungarian)

Szirmai, O., S. Czóbel, J. Nagy 2005: Relationship between landuse changes and forest steppe species in new Hungarian forest steppe area. - Cereal Research Communications, 33, pp. 313-316. 
Török, P., E. Vida, B. Deák, S. Lengyel, B. Tóthmérész 2011: Grassland restoration on former croplands in Europe: An assessment of applicability of techniques and costs. - Biodiversity and Conservation, 20, pp. 2311-2332.

Tóth, A. 1998: Veszélyeztetett löszgyep reliktum foltok a nagykunsági kunhalmokon [Hazardous loess relict patches on the kurgans of the Nagykunság]. - Kitaibelia, 3, pp. 329-330. (in Hungarian)

Tóth, A., Cs.A. Tóth 2003: Kunhalmok állapotfelmérése a Hortobágy déli pusztáin és a szomszédos hajdúsági területeken [Kurgan survey in the southern plains of Hortobágy and the adjacent area of Hajdúság]. - In: Tóth, A. (Ed): Tisza-völgyi tájváltozások [Landscape changes in the Tisza Valley]. Alföld-kutatásért Alapítvány, Kisújszállás, pp. 95-111. (in Hungarian)

Tóth, C., K. Joó, A. Barczi 2015: Lyukas Mound: One of the many prehistoric tumuli in the Great Plain. In: Lóczy, D. (Ed): Landscapes and Landforms of Hungary. Springer, Dordrecht, pp. 255-262.

Tóth, Cs.A. 2006: Az országos kunhalom-felmérés eredményei és tapasztalatai: A természetvédelmi szempontból értékes kunhalmok kijelölése [Results and experiences of the national kurgan survey: Designation of valuable kurgans in a natural conservation point of view]. - In: Kertész, Á., Z. Dövényi, K. Kocsis (Eds): III. Conference of Hungarian Geography, Abstract Volume, Budapest. (in Hungarian)

Tóth, Cs.A., M. Pethe, A. Hatházi 2014: The application of earth science-based analyses on a twin-kurgan in Northern Hungary. - Carpathian Journal of Earth And Environmental Sciences, 9, pp. 11-20.

Troels-Smith, J. 1955: Karakterisering af lose jordater [Characterization of unconsolidated sediments]. Danmarks Geologiske Undersogelse, 4/3, pp. 1-73. (in Danish).

Újvári, G., M. Molnár, Á. Novothny, B. Páll-Gergely, J. Kovács, A. Várhegyi 2014: AMS 14C and OSL/ IRSL dating of the Dunaszekcső loess sequence (Hungary): Chronology for 20 to $150 \mathrm{ka}$ and implications for establishing reliable age-depth models for the last $40 \mathrm{ka}$. - Quaternary Science Reviews, 106, pp. 140-154.

Vaday, A. 2004: Chronological tables. - In: Visy, Z. (Ed): Hungarian Archeology at the Millenium. Nemzeti Kulturális Örökség Minisztériumának Kiadványa, Budapest, pp. 473-477.

Vanuxem, L. 1843: On the ancient oyster shell deposits observed near the Atlantic coast of the United States. - Reports of the Association of the First, Second and Third meetings of the American Geologists and Naturalists. Gould, Kendall and Lincoln Press, Boston, pp. 21-23.

Vértes, L., D. Jánossy, M. Herrmann, J. Stieber 1956: Ausgrabungen in der Petényi und Peskő Höhle (Bükk Gebirge) [Excavations in the Petényi and Peskő Caves (Bükk Hills)]. - Folia Archaeologica, 8, pp. 3-22.

Vona, M., K. Penksza 2004: A szentesi Kántor-halom vegetációjának változása és ennek összefüggése a talaj vízháztartásával [Change of the vegetation on the Kantor kurgan and its relations with the soil water regime]. - Tájökológiai Lapok, 2, pp. 341-348. (in Hungarian)

Vörös, G. 2002: A vaskúti szarmata halmok leletei. Adatok a szarmata koporsók és gerendakamrák köréhez [Findings of the Sarmatian mounds in Vaskút. Data about the Sarmatian coffins and timber chambers]. Les annales du Musée Ferenc Móra, Studia Archaeologica, 8, pp. 157-176. (in Hungarian)

Walker, M., S. Johnsen, S.O. Rasmussen, T. Popp, J.P. Steffensen, P. Gibbard, W. Hoek, J. Lowe, J. Adrews, S. Björck, W. Cwynar, K. Hughen, P. Kershaw, B. Kromer, T. Litt, D.J. Lowe, T. Nakagawa, R. Newnham, J. Schwander 2009: Formal definition and dating of the GSSP (Global Stratotype Section and Point) for the base of the Holocene using the Greenland NGRIP ice core, and selected auxiliary records. - Journal of Quaternary Science, 24, pp. 3-17.

Wesche, K., J. Treiber 2012: Abiotic and biotic determinants of steppe productivity and performancea view from Central Asia. - In: Werger, M.J.A., M.A. van Staalduinen (Eds): Eurasian Steppes. Ecological Problems and Livelihoods in a Changing World. Springer, Dordrech, pp. 3-43.

Willis, K.J., M. Braun, P. Sümegi, A. Tóth 1997: Does soil change cause vegetation change or vice-versa? A temporal perspective from Hungary. - Ecology, 78, pp. 740-750.

Willis, K.J., P. Sümegi, M. Braun, K.D. Bennett, A. Tóth 1998: Prehistoric land degradation In Hungary: Who, how and why? - Antiquity, 72, pp. 101-113. 
Zhu, R., Q. Liu, M.J. Jackson 2004: Paleoenvironmental significance of the magnetic fabrics in Chinese loess-paleosols since the last interglacial (<130 ka). - Earth and Planetary Science Letters, 221, pp. 55-69.

Zólyomi, B. 1957: Der Tatarenahorn-Eichen-Lösswald der zonalen Waldsteppe [Oak forests with Tatarian Maple in the forest steppe zone]. - Acta Botanica Hungarica, 3, pp. 401-424.

Zólyomi, B. 1969: Földvárak, sáncok, határmezsgyék és a természetvédelem [Earthworks, earthen fortifications, unplowed land strips and nature conservation]. - Természet Világa, 100, pp. 550-553. (in Hungarian)

Zólyomi, B. 1987: Coenotone, ecotone and their role in preserving relic species. - Acta Botanica Hungarica, 33, pp. 3-18.

Zólyomi, B., G. Fekete 1994: The Pannonian loess steppe: Differentation in space and time. - Abstracta Botanica, 18, pp. 29-41. 